
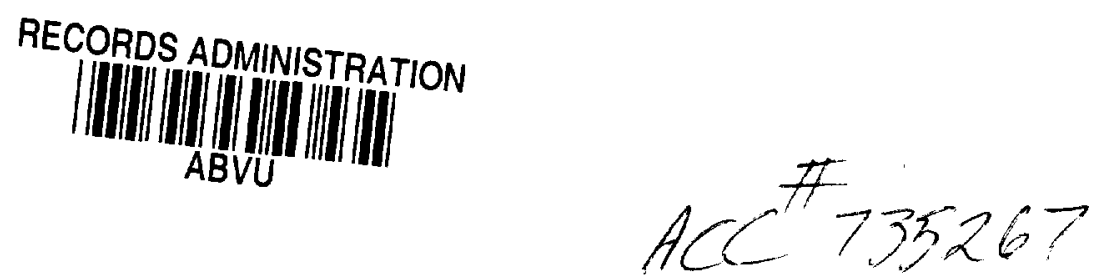

DP-MS-80-27

\title{
SIGNIFICANCE OF RADIATION EFFECTS IN SOLID RADIOACTIVE WASTE
}

by

Philip H. Permar and William R. McDonell

Savannah River Laboratory

E. I. du Pont de Nemours \& Company

Aiken, South Carolina 29808

To be published in the ASTM Proceedings

10th Symposium on Effects of Radiation on Materials

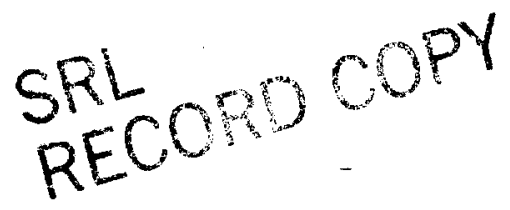

This paper was prepared in connection with work under Contract No. DE-ACO9-76SROOOOI with the U.S. Department of Energy. By acceptance of this paper, the publisher and/or recipient acknowledges es the U.S. Government's right to retain a nonexclusive, royaltyfree license in and to any copyright covering this paper, along with the right to reproduce and to authorize others to reproduce all or part of the coprighted paper. 


\section{ABSTRACT}

Proposed NRC criteria for disposal of high-level nuclear waste require development of waste packages to contain radionuclides for at least 1000 years, and design of repositories to prevent radionuclide release at an annual rate greater than 1 part in 100000 of the total activity. The high-level wastes that are now temporarily stored as aqueous salts, sludges, and calcines must be converted to high-integrity solid forms that resist deterioration from radiation and other effects of long-term storage. Spent fuel may be encapsulated for similar long-term storage.

Candidate waste forms beside the spent fuel elements themselves, include borosilicate and related glasses, mineral-like crystalline ceramics, concrete formulations, and metal-matrix glass or ceramic composites. These waste forms will sustain damage produced by beta-gamma radiation up to $10^{12}$ rads, by alpha radiation up to $10^{19}$ particles/g, by internal helium generation greater than about 0.1 atom percent, and by the atom transmutations accompanying radioactive decay. Current data indicate that under these conditions the glass forms suffer only minor volume changes, stored energy deposition, and leachability effects.. The crystalline ceramics appear susceptible to the potentially more severe alterations accompanying metamictization and natural analogs of candidate materials are being examined to establish their suitability as waste forms. Helium concentrations in the waste forms are generally below thresholds for severe damage in either glass or crystalline ceramics at low temperatures, but microstructural effects are not well characterized. Transmutation effects remain to be established. 
SIGNIFICANCE OF RADIATION EFFECTS

IN SOLID RADIOACTIVE WASTE

by Philip H. Permar and William R. McDonell

\section{INTRODUCTION}

Radiation effects on materials must be considered in virtually every phase of nuclear fission technology from reactor operation to disposal of radioactive waste. In waste management, radiation effects become important if they interfere with containment of the waste. Since required containment times are many thousands of years, knowledge of the long-term cumulative effects of radiation on the waste forms is essential. This review describes the current regulatory radiation performance objectives, the origins and characteristics of radioactive waste and the candidate waste forms, and the nature and magnitude of the radiation effects that might be experienced.

\section{WASTE MANAGEMENT OBJECTIVES}

The Nuclear Regulatory Commission is responsible for establishlishing the performance objectives that radioactive waste management plans must meet. Current reference plans call for a multiplebarrier waste package to be emplaced in a deep geologic repository [1]. The redundant, multiple-barrier approach is proposed to compensate for uncertainty in predicting behavior of geologic systems over long periods of time. The primary barrier to the release of radionuclides is the waste package, which includes the waste form, canister, and overpacks. According to preliminary NRC criteria 
10CFR60, each waste package must provide reasonable assurance of the containment of radionuclides for at least the first 1000 years after decomissioning of the geologic repository. The waste package and underground facility must be designed so that radionuclides will at no time be released from the underground facility at an annual rate greater than one part in 100000 of the total contained activity.

These requirements indicate the problems that waste materials scientists must solve. They must predict the effect of 1000 years of beta-gamma radiation, and of greater than 100000 years of alpha radiation on waste forms, canisters, overpacks, backfills, and the near-field geological environment. Their predictions must be accurate enough to be useful in the mathematical modeling of radioisotope release mechanisms. Finally, their programs must be broad enough to cover the wide variety of materials and conditions involved in the multiple-barrier system.

\section{ORIGINS AND CBARACTERISTICS OF RADIOACTIVE WASTE}

Because radioactive wastes have been accumulating for more than 35 years in many locations under a great variety of conditions: a precise listing is a difficult task. The best summary of the accumulated radioactive waste in the USA is found in Appendix D of the Report to the President by the Interagency Review Group on Nuclear Waste Management [2]. This summary is being updated by Oak Ridge National Laboratory to provide an Integrated Data Base for the National Plan for Nuclear Waste Management announced by President Carter on 12 Feb. 1980. 
The classes and quantities of all existing waste, and the percent of the waste in commercial sectors, are as shown in Table 1.

Liquid high-level waste is produced during chemical reprocessing of irradiated reactor fuel and target elements, principally at government sites. The only liquid high-level commercial waste (600 000 gallons) resulted from early stage reprocessing of spent fuel elements at West Valley, New York. The Iiquid high-level wastes have largely been evaporated to salt-sludge mixtures or calcined to solids for temporary tank storage. Transuranic wastes are typically residues and contaminated equipment resulting from defense materials manufacturing. The commercial fuel elements are currently being maintained essentially as they came out of the reactors. Almost all of the high-level, transuranic and spent fuel element wastes are stored temporarily in ways that require continuous monitoring and surveillance.

Low-level waste produced in a variety of nuclear, medical, and industrial operations is now placed in shallow land burial sites. Natural radioactive residues are left by mining and milling operations of uranium and other radioactive ores. Consideration of radiation effects in this review will be limited to the high-level defense and commercial wastes and to the unprocessed spent fuel from commercial reactors. As shown in Table 2 [3], most of the existing high-level nuclear waste in the United States has been generated in defense activities; i.e., in 
producting plutonium and tritium for nuclear weapons at the DOE plants at the Hanford Plant near Richland, WA [4], and at the Savannah River Plant (SRP) near Aiken, SC [5], and in processing spent naval reactor fuels at the Idaho Chemical Processing Plant (ICPP) near Idaho Falls, ID [5]. An inventory of approximately 75 million gallons of high-level defense waste containing about $9 \times$ $10^{8} \mathrm{Ci}$ of radioactivity is on hand. In addition, approximately $3.5 \times 10^{8} \mathrm{Ci}$ of radioactivity exist at hanford in the form of separated Cs-137 and Sr-90, contained in capsules and stored in water basins. Production of waste is continuing at the rate of 0.5-1 million gallons per year, and in 1990 the inventory of defense radionuclides is projected to reach $1.8 \times 10^{9} \mathrm{Ci}$. Average chemical composition of SRP waste, typical of high-level defense wastes before removal of $\mathrm{Sr}-90$ and $\mathrm{Cs}-137$, is shown in Table 3 , and the decay of its radionuclide content is illustrated in Figure 1. High activity fission products generally decay to low levels within about 1000 years, leaving low-activity fission products and residual actinides that persist for more than a million years.

A comparable inventory of about $1.9 \times 10^{9} \mathrm{Ci}$ of waste radionuclides is also on hand in spent U.S. power reactor fuels, and by 1990 this inventory is projected to reach $1.4 \times 10^{10} \mathrm{Ci}$. Since the present U.S. policy is to defer reprocessing of commercial power reactor fuels, planning for high-level waste management based on any future processing of these fuels is on a contingency basis 
only. The highly radioactive acid wastes that result from commercial fuel reprocessing, $4000 \mathrm{Ci}$ of radionuclides per gallon (30 $\left.000 \mathrm{Ci} / \mathrm{ft}^{3}\right)$, are assumed to be calcined for subsequent immobilization in a high-integrity disposal form. Typical materials in high-level wastes from a variety of commercial reactor types are shown in Table 4 [7]. In the commercial wastes, radioactive fission products and residual actinides constitute a much greater fraction of the solids than in the defense wastes.

\section{CANDIDATE WASTE FORMS AND ENGINEERED BARRIERS}

High-level wastes are immobilized by placing them in a highintegrity form which has a low potential for radionuclide release. The purpose of the high-integrity form is to provide the initial barrier against radionuclide release from waste storage or disposal, and to prevent release of radionuclides if any transportation accidents occur during waste shipment. The waste form is an important element of the disposal system (which includes a primary canister (I), overpacks, backfills, and the geologic medium) and must be compatible with that system.

The leading candidate waste form under development for processed commercial and defense wastes is borosilicate glass. Other candidate forms include the spent fuel elements themselves, other glasses, special concrete formulations, mineral-1ike crystalline ceramics, and metal-matrix glass or ceramic composites. Brief descriptions of these candidate waste forms are summarized in Table 5 [8-40]. These descriptions are based on a recent preliminary study of alternative forms for SRP defense waste [8].

In addition to the waste forms, there are two sets of engineered barriers to retard the release of radioactive waste to the geologic host rock, as illustrated in Figure 2. 
The first set of engineered barriers is the "overpack", designed to provide complete containment of radionuclides for a minimum of 1000 years. The overpack consists of an inner canister (II), a chemical buffer designed to control the pH and oxidation potential of any entering water, and an outer canister (III) of a highly corrosion-resistant material such as titanium.

The second set of engineered barriers is the backfill designed to retard the entrance of groundwater and to adsorb any radionuclides that might have been leached from the waste form. The backfill consists of a retrieval sleeve designed to facilitate the retrieval of the waste canister and overpack, a multipurpose backfill consisting of hydrophobic materials to prevent the passage of water and also containing ion-adsorbing materials to retard the outward migration of actinides. It is intended that the backfill be essentially impervious to water, resisting flow for hundreds of years. Also, the adsorptive ability of the backfill is expected to equal that of the host rock and natural geologic barriers between the repository and the biosphere.

\section{RADIATION EFFECTS}

Three principal mechanisms exist for incurring radiation damage in radioactive waste forms and surrounding materials [41-53].

1. Charged particles (alpha and beta particles, recoil atoms, fission fragments), neutrons, or gamma rays emitted during radioactive decay of waste constituents lose energy by electronic excitation and ionization and by elastic atomic collisions. This energy loss disrupts chemical bonds and displaces atoms, producing dimensional and property changes in exposed materials and causing energy to be stored in non-equilibrium structures. 
2. Alpha particles produced during decay of actinide atoms accumulate as helium atoms in the waste form or its container. Such gas accumulation may distort and mechanically weaken the waste form and/or pressurize the container.

3. Radioactive decay causes waste constituents to change their chemical identity. Such transmutations may alter chemical bonding, valence, and coordination number in ways that affect the structure and properties of the waste form. Characterization of the practical consequences of these radiation effects is relatively well advanced for the borosilicate glasses, but remains in early stages for the other waste forms and containment materials. Previous experience with ceramic materials, including natural mineral substances, is being used to guide development of the crystalline ceramic waste forms. For the concrete and composite forms, only general projections based on behavior of individual constituents are available. This review will emphasize the effects of radiation on the glass and crystalline ceramic waste forms. Where specific characterizations are lacking, the behavior of prototype materials will be described, along with deviations expected to result from incorporation of waste constituents and other special tailoring.

Critical characteristics of the waste form and other materials potentially affected by radiation exposure include volume (density), stored energy, leachability, and phase stability.

Changes in volume serve as a fundamental indicator of the susceptibility of a material to radiation damage and can lead to 
cracking, reduced thermal conductivity, increased chemical reactivity and leachability, and containment failure of the waste form [50]. Stored energy is a similarly basic measure of radiation damage, with the potential for producting deleterious overheating of the irradiated material on release. Leachability changes, generally secondary consequences of radiation exposure, are the effects of greatest practical concern in waste form performance. Phase stability is necessary for preservation of properties initially invested in the materials. Helium accumulation in waste forms can produce swelling and cracking analogous to (and in conjunction with) the primary radiation exposure. Atom transformations accompanying radioactive decay can produce similar effects and lead potentially to enchanced leachability.

\section{Projected Radiation Exposures And Temperatures}

Not all types of radiation are equally damaging to waste forms. Only the beta-gamma radiations emitted by the fission products, and the alpha particles and associated recoil atoms produced by residual actinides contribute significant effects $[42,43]$. Fission fragments from spontaneous fission, and neutrons from $(\alpha, n)$ reactions or spontaneous fission can be neglected because of the small number of such events. Projected exposures of defense and commercial wastes to beta-gamma and alpha radiation are shown in 
Table 6; commercial waste exposures are generally 100 times greater than the defense waste exposures $[10,13,54]$. Accumulated doses produced by beta-gamma radiation in a typical defense waste form are compared with the corresponding alpha radiation doses in Figure 3. The beta-gama doses are incurred essentially all within the initial 1000 years; the alpha doses in defense wastes are relatively small during the initial 1000 years, and reach values comparable to beta-gamma doses only after more than 100000 years. The alpha doses produced in comercial waste forms are considerably higher, reaching values comparable to beta-gamma doses within 1000 years. Accumulated alpha radiation exposures up to 1 million years are compared for defense wastes and commercial wastes in Figure 4.

Temperatures of the waste forms depend on their radionuclide content, with significant self-heating experienced only during the initial period of high-activity fission product decay. Surface temperatures of commercial waste forms will probably not be allowed to exceed $200^{\circ} \mathrm{C}$, but center temperatures may range up to $500^{\circ} \mathrm{C}$ during the initial period [10]: defense waste temperatures will range $100-200^{\circ} \mathrm{C}$.

\section{Effect of Chemical Bond Type}

The relative susceptibility of materials to damage by betagamma and alpha radiation depends on the type of chemical bonding the material exhibits [41]. Waste forms (either crystalline or glass) and surrounding material tend to be mineral substances, 
which are characterized by mixed covalent and ionic bending. Such materials are more or less susceptible to radiation effects due to the ionization processes produced by beta-gamma exposures as well as to the atom displacements produced by alpha particles and recoil nuclei.

Covalently-bonded materials, such as silica $\left(\mathrm{SiO}_{2}\right)$ [55], with a rigid, often complex arrangement of constituent atoms (including interstices or free volume between atoms) tolerate little radiation-induced disorder without significant changes in atomic structure. Ionically-bonded materials, such as $\mathrm{NaCl}$, form simple close-packed structures, which can accomodate extensive disorder without large structural effects. Thus mineral materials with mixed covalent and ionic bonding become increasingly resistant to structural change by either beta-gamma or alpha radiation as ionic bonding increases. Radiation effects in common glasses will be dependent upon composition, since network formers such as $\mathrm{SiO}_{2}, \mathrm{~B}_{2} \mathrm{O}_{3}$, and $\mathrm{Al}_{2} \mathrm{O}_{3}$ are covalently bonded into rigid configurations, and modifiers such as $\mathrm{Na}, \mathrm{Ca}, \mathrm{Ba}$, and $\mathrm{Sr}$ are ionically bonded into interstices in the network [10].

\section{Beta-Gamma Radiation Effects}

\section{Waste Forms}

Beta-gamma radiation is commonly supposed not to make a major contribution to radiation damage of waste forms because of the relatively low number of displaced atoms generated by beta-gamma radiation compared to alpha particles and associated recoil 
atoms $[42,43]$. The fraction of the energy deposited by a given type of radiation that can be expended in elastic collisions producing atomic displocements in a material depends on the energy and mass equivalent of the radiation. Previously presented calculations of the energy expended in such elastic collisions are shown in Table 7 and illustrated in Figure 5 for several types of radiation in a typical comercial waste. The beta-gamma radiation to which the waste is exposed contributes only a small fraction of the energy available for atom displacements. Most of the atom displacements are produced by the alpha recoil nuclei, with a lesser fraction produced by the alpha particles themselves. This analysis neglects the structural effects in mineral substances resulting from ionization processes. The well-documented behavior of vitreous silica $\left(\mathrm{SiO}_{2}\right)$, a substance closely related to the glass waste forms, evidences such effects in covalentlybonded structures $[52,56-67]$. Vitreous silica exposed to a variety of radiations, including gamma rays, accelerator electrons (like beta-particles), and helium ions (like alpha particles), exhibits a characteristic volume decrease, termed radiation compaction [56-59]. This compaction is attributed generally to disruption of silicon-oxygen bonds in the glass network in a way that reduces the free volume of the structure. Network-formers such as aluminum, and modifiers such as hydrogen reverse the radiation compaction process, and promote radiation expansion, apparently by occupation of interstices in the structure $[60,67]$. 
The radiation compaction of vitreous silica ranges up to several volume percent $[52,59,64]$. Accelerator electron exposures of $10^{12}$ rads, corresponding to maximum beta-gamma doses in commercial wastes, produce compactions of about $1 \%[65]$, the same magnitude as the dilations produced by alpha particle and recoil nuclei exposures of commercial waste glasses during long-term exposures. The beta-gamma radiation effects in specific borosilicate waste glasses are not well characterized, but the potential for significant short-term structural damage may be greater than previously supposed.

To the extent that they share the damage-susceptible, covalently-bonded structures of the glassy materials, the crystalline waste forms may also be susceptible to effects of beta-ganma radiation.

\section{Package and Respository Materials}

Comprehensive characterization of beta-gamma effects will require evaluation of other components of the waste package, such as canisters and overpacks, and of the backfill and surrounding repository rock. The canister configurations now under consideration for nuclear waste disposal will expose these materials to gamma doses of about $10^{10}$ to $10^{11}$ rads [68]. Interactions of these materials with waste forms and canisters and their ability to restrict migration of water and waste components are potentially affected by such radiation exposures. Candidate repository materials include basalt, granite, shale, and salt. 
Almost no radiation damage information is currently available for granite, basalt, and shale, but rock salt is subject to formation of colloidal sodium particles $(0.001$ to $0.1 \%)[68-70]$. The effects of such microstructural changes on the waste-containtment properties of salt remain to be assessed. Other studies indicate that effects of gamma radiation on aluminosilicate minerals representative of repository media may also be important [71].

\section{Alpha Radiation Effects}

Alpha particles lose energy mainly by electron ionization, with some atom collisions, and leave helium atoms in the structure; the recoil nuclei lose energy mainly by atom collisions (Table 7). Displacement densities resulting from the atom collisions, one displacement per atom (dpa) or less [50], are low compared to those produced in fast fission or thermonuclear reactors [72], but may result in significant effects to damagesusceptible crystalline and glass forms. The effects of alpha radiation have been simulated by doping the waste forms with the short-lived, alpha-emitting radionuclides $\mathrm{Pu}-238$ or $\mathrm{C}_{\mathrm{m}}-244$, in concentrations up to $8 \%$.

\section{Volume Changes}

Simple vitreous silica and borosilicate glasses tend to compact initially $[60,73]$, but glasses containing wastes may initially compact or expand, depending on composition, with volume changes not exceeding $\pm 1 \%$ at high exposures, as shown in Figure 6 . Volume 
changes level off at about $2 \times 10^{18} \alpha / g$, an exposure corresponding to 2000 years for commercial waste, but not reached for defense wastes. Behavior of the difterent compositions relate to bonding characteristics as previously described; the waste glasses generally expand more rapidly with higher contents of network modifiers or waste atoms. Partial devitrification diminishes major compactions and converts minor compactions into major expansions as shown in Figure $7[74,75]$. The maximum expansions observed can be tolerated by present canister designs [10].

No large-scale fracturing of glass waste forms as a result of radiation-induced volume changes has been reported $[47,48,53]$, although microcracking was observed in test specimens containing simulated defense waste exposed to greater than $2 \times 10^{17} \alpha / g$ [53].

\section{Stored Energy Buildup}

The stored energies of commercial waste glasses are generally less than $50 \mathrm{cal} / \mathrm{g}$ for exposures up to $10^{19} \alpha / \mathrm{g}[10,43]$. Saturation is reached at $4 \times 10^{18} \alpha / \mathrm{g}$, corresponding to about 20000 years in a repository (Figure 8 ). The stored energy accumulated at low temperatures $\left(25^{\circ} \mathrm{C}\right)$ is released on heating over the temperature range $200-400^{\circ} \mathrm{C}$, but no sudden release occurs that would heat a waste form above $300^{\circ} \mathrm{C}$.

\section{Radiation Effects on Leachability of Glass}

Long-term exposure to internally generated alpha particles is reported to have very little effect on the leachability of waste 
glasses $[10,47,48,53,54,76,77\}$. Results of leach tests on fully radioactive waste glasses in low-temperature deionized water are in close agreement with those on nonradioactive glasses [78].

Glass specimens exposed to external radiation, however, have exhibited enhanced susceptibility to attack in aggressive leach media. Crazing and flaking of surfaces of glass vessels containing highly alpha radioactive solutions at low temperature have been observed [79]. Accelerator beams of low-energy heavy particles simulating alpha recoil atoms are reported to greatly increase rates of surface attack of borosilicate glasses in sea water or salt solutions at $100^{\circ} \mathrm{C}$ : waste glass forms with exposures corresponding to a few thousand years storage are predicted to dissolve in NaCl-rich hydrothermal solutions within 100 years [80]. These effects are attributed to preferential etching of the heavy particle tracks in the exposed material; further investigation of their significance is needed.

\section{Metamictization of Crystalline Materials and Devitrification of Glass}

Long-term radiation effects in crystalline substances can be more severe than in glasses, as evidenced by metamict minerals in nature [81-84]. The metamict minerals, containing naturally radioactive uranium and thorium, are once-crystalline substances that have been converted to glass-like amorphous forms by long-term exposures to alpha particles and recoil nuclei. Along with loss of crystal structure, the metamict minerals may be physically and 
chemically altered in natural environments by hydrothermal and weathering reactions. They are thus studied as models for crystalline and glass waste forms subject to long-term radiation.

The mineral zircon Itetragonal $\mathrm{ZrSiO}_{4}$ containing less than 4 wt percent $(\mathrm{U}, \mathrm{Th}) \mathrm{O}_{2}$ ] is a well known metamict material. Volume increases which evidence metamictization begin at exposures of about $10^{18} \alpha / g$ and reach $15 \%$ at exposures over $10^{19} \alpha / g$ [83]. Hydration accompanying metamictization introduces strains that result in extensive fracturing. Metamict zircon is dissolved by dilute acids at a much higher rate than non-metamict zircon and preferential leaching of uranium and thorium along fractures is reported.

The susceptibility of mineral structures to metamictization varies widely and many minerals containing naturally radioactive nuclides resist this type of radiation damage. Metamictization appears to be promoted by (1) complex compositions, (2) some degree of covalent bond character, and (3) channels or interstitial spaces which accormodate displaced atoms or absorbed water [83]. Prominent among the minerals with demonstrated resistance to metamictization and related effects are the thorium and uranium ore constituents monazite (typically monoclinic $\mathrm{CePO}_{4}$ with up to $20 \%$ thorium-uranium oxide), thorianite $\left[(\mathrm{Th}, \mathrm{U}) \mathrm{O}_{2}\right]$, and uranite $\left(\mathrm{UO}_{2+\mathrm{x}}\right)[83,85,86]$. The $\mathrm{UO}_{2}$ ores of the Oklo natural fission reactor in Gabon, Africa, for example, have been shown to retain actinides formed longer than 2 billion years ago $[87,88]$. Such observations relate to the 
stability of unprocessed spent fuel as a waste form, as well as to that of the crystalline ceramic forms. The natural analogs of other actinide host phases in crystalline waste forms being examined for metamictization effects include the SYNROC constituents zirconalite $\left(\mathrm{CaZrTi}_{2} \mathrm{O}_{7}\right)$ and perovskite $\left(\mathrm{CaTiO}_{3}\right)$. Both constituents appear resistant to metamictization in SYNROC compositions containing representative waste loadings [89]. Crystalline ceramics that do not undergo metamictization are more resistant to deleterious radiation damage [90]. At alpha exposures producing one dpa, volume increases of ceramic materials generally range up to a few percent. Polycrystalline ceramics with noncubic structures, such as aluminum oxide, suffer grain boundary separations produced by anisotropic dimensional changes, which drastically decreases their mechanical strength. In cubic ceramics, only minor strengthening or weakening is observed.

Radiation has little effect on devitrification of waste glasses, with neither the devitrification products nor their rate of formation believed to be significantly affected [10]. This result is evidenced by the similarify in devitrification behavior of radioactive and nonradioactive specimens. Radiation effects are largely annealed out at the temperatures at which devitrification occurs.

Concern over metamictization in glass waste forms is confined to effects of radiation on crystalline phases in partially devitrified glass [75]. Vitreous specimens of a simulated waste 


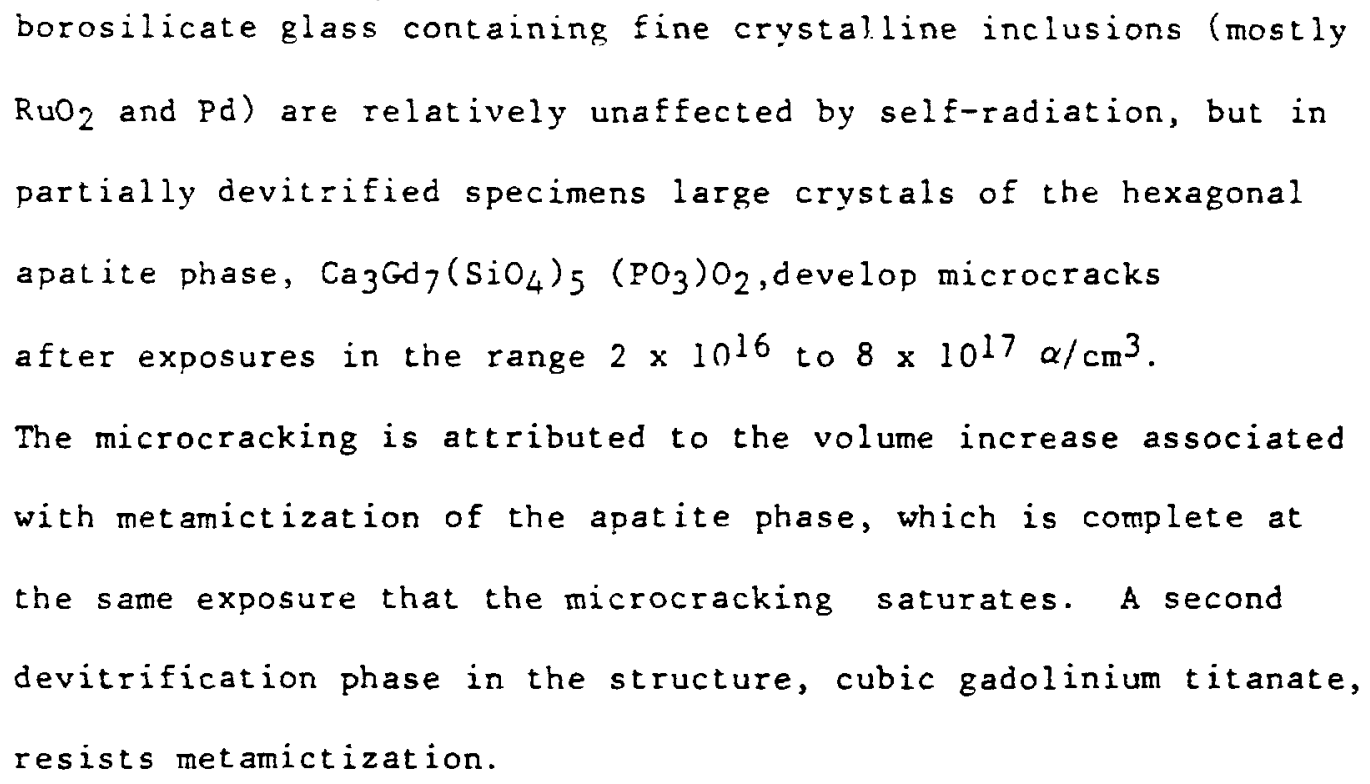

\section{Helium Accumulation}

Helium concentrations generated by alpha decay over $10^{6}$ years in commercial waste forms are typically 1000 atomic ppm $(0.1$ atom $\%)$ and in defense waste forms are a factor of 100 lower, assuming homogeneous distributions [50]. The helium concentrations generated in commercial wastes are somewhat higher than those in fast breeder reactor materials [72], but much lower than those produced by alpha decay in ${ }^{238} \mathrm{PuO}_{2}$ heat sources [91] or in surface layers of first wall materials for thermonuclear reactors [92].

Consequences of helium deposition depend on whether the gas is retained in the waste form. Helium mobility in glasses is sensitive to composition and structure, with large free volumes or interstices promoting diffusion [93-101]. The relatively high diffusivities of helium in high-purity glasses of simple network 
formers $\left(\mathrm{SiO}_{2}, \mathrm{~B}_{2} \mathrm{O}_{3}\right)$ are diminished by addition of modifiers

0

( $\mathrm{Li} 2 \mathrm{l}^{\prime}, \mathrm{Na}_{2} \mathrm{O}, \mathrm{BaO}$ ) which compact the network. Vitreous silica

implanted with high surface concentrations of helium by exposure

to accelerator He ions shows none of the low-temperature bister-

ing suffered by glasses with lower diffusivity (for example, $65 \%$

$\left.\mathrm{SiO}_{2}-35 \% \mathrm{Li}_{2} \mathrm{O}\right)$ implanted with helium under the same condi-

tions $[101,103]$. The high diffusivity of helium in vitreous

silica permits its migration away from the implanted surface be-

fore threshold concentrations for blistering are reached. Compac-

tions of the network structure by radiation exposures (beta-gamma

and alpha), and filling of interstices with network modifiers or

impurity atoms of the waste additions could inhibit helium migra-

tion in waste glasses, diminishing helium release and enhancing

retention effects.

Studies of He behavior in simulated waste glasses doped with Cro-244 indicates diffusion proceeds with a normal Arrhenius dependence on temperature at low helium concentrations, but is significantly inhibited at higher concentrations by concurrent radiation damage effects [44]. Maximum He pressures in representative canisters containing either commercial or defense waste glasses are projected to be well below design limits $[10,44]$.

Helium retained in glass waste forms and not trapped in internal cracks or voids must either be held within interstices of the glass network or agglomerated into small gas bubbles, producing. swelling. No microstructural evidence of gas bubble formation at low temperature has been reported for glasses containing helium 
at the relatively low concentrations expected in waste forms. At higher concentrations, helium implanted into surfaces of low diffusivity glasses is agglomerated into many micron-size bubbles, which interconnect to form surface blisters [103]. Similar blisters have been observed on $\mathrm{Cm}_{\mathrm{m}}-244$ and $\mathrm{Pu}-238$ doped specimens of a simulated defense waste glass during beam heating of a fracture surface in a scanning electron microscope after exposures greater than $2 \times 10^{17} \mathrm{\alpha} / \mathrm{g}[53]$. These specimens also exhibit a welldefined microcracking, apparently caused either by radiation damage or helium deposition, or by a synergistic combination of both effects (Figure 9 ).

Microstructural effects of helium generated in crystalline materials are somewhat better characterized than in glass forms. At concentrations up to several atom $\%$ in alpha-emitting $238 \mathrm{PuO}_{2}$, for example, He forms no microscopically resolvable bubbles at low temperatures $[104,105]$. Heating to temperatures greater than one-half the melting point of the oxide is necessary to produce observable bubbles located on grain boundaries of the structure. Helium accumulation should thus prove to be a minor problem in the high-melting crystalline waste forms.

\section{Atom Transmutations}

Effects of atom transmutation resulting from radioactive decays are not yet well characterized for solid waste forms, but could be important in both glasses and crystalline ceramics. In the glass waste forms, changes in valence and atomic volumes 


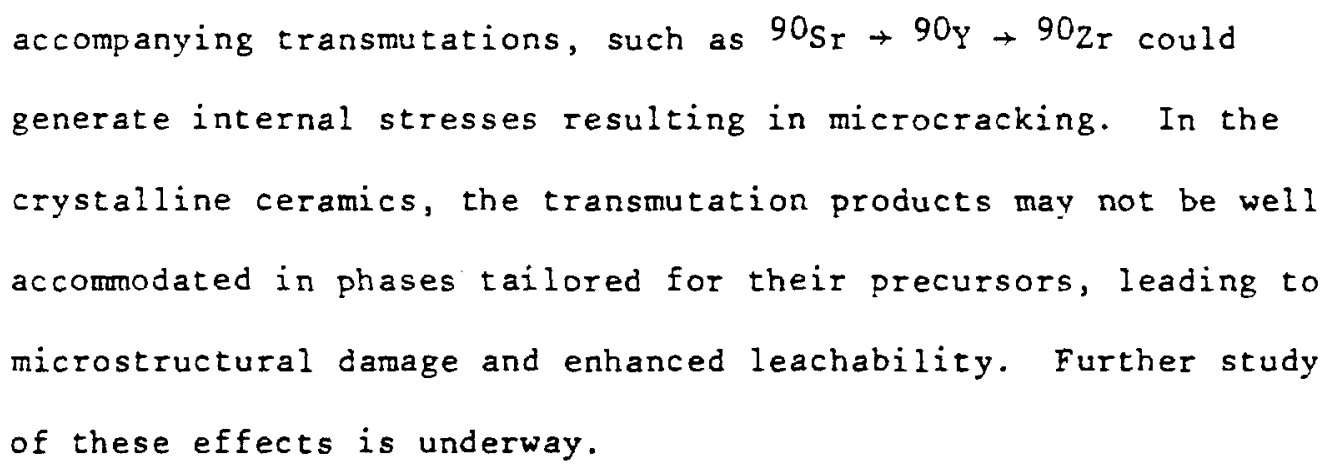

\section{SUMMARY}

1. Disposal of high-level nuclear wastes in the U.S. will be guided by projected NRC regulations limiting release of radioactivity from geological repositories to an annual rate no greater than 1 part in 100000 of the total activity contained in the repository. The redundant and multi-barrier approach devised to meet this criterion requires prediction of effects of radiation in waste forms and surrounding materials for more than 100 000 years, during which the waste decays to low radiation levels.

2. Most existing high-level waste is stored at government sites where it was generated during defense materials production. In addition, there is an increasing inventory of spent fuel elements from commercial power reactors, which must also be stored either as spent fuel or as liquid waste resulting from chemical processing.

3. Both the defense and commercial high-level wastes must be immobilized in high-integrity solid forms, such as borosilicate glass or crystalline ceramics, for repository disposal. Commercial spent fuel elements may be disposed of without reprocessing. 
4. Radiation effects expected in the waste forms include structural damage due to beta-gamma and alpha radiation, deposition of helium, and transmutation of decay atoms.

5. Effects of beta-gamma emitting fission products producing doses up to 1012 rads over 1000 years are not well characterized, but may be significant for repository materials as well as radioactive waste forms.

6. Effects of the alpha radiation from residual actinides producing greater than $10^{19} \alpha / g$ in glass waste forms include volume changes less than $\pm 1 \%$, stored energy deposition less than $50 \mathrm{cal} / \mathrm{g}$ released over a wide temperature range, and no pronounced increase in leachability in low-temperature water. Investigations of leachability effects in more aggressive media are proceeding.

7. Crystalline ceramic forms are potentially susceptible to metamictization effects, including large volume increases accompanying loss of crystal structure. However, many naturally occurring minerals including the uranium- and thorium-containing minerals monazite and uraninite resist metamictization, and the natural analogs of other actinide host phases are being examined to assure their stability.

8. Helium concentrations up to 0.1 atom $\%$ accumulated during alpha decay are below thresholds for severe canister pressurization or waste form damage at low temperatures. Microstructural effects including microcracking require further investigation. 
9. Atom transmutation effects, as yet not well defined, couid produce potentially deleterious changes in both glass and ceramic waste forms.

10. No grossly detrimental behavior under irradiation has been observed for either the glass or crystalline ceramic waste forms, but additional study is needed for prediction of long-term effects.

\section{ACKNOWLEDGEMENT}

The authors are grateful for helpful prepublication reviews of this paper by several of their colleagues at Savannah River, including N. E. Bibler, T. H. Gould, J. A. Stone, G. G. Wicks, and J. R. Wiley, and by F. P. Roberts of Battelle-Pacific Northwest Laboratories. 


\section{REFERENCES}

1. White, I. A., Bell, M. A., Rohrer, D. M., Regulation of Geologic Repositories for the Disposal of High-Level Radioactive Wastes, Proceedings of the Materials Research Society, 1979 Annual Meeting, Cambridge, Mass. (to be published).

2. Report to the President by the Interagency Review Group on Nuclear Waste Management, TID-29442, National Technical Information Service. U. S. Dept. of Commerce, Springfield, VA, March 1979.

3. Strategy Document - Long Term High Level Waste Technology Program, USDOE Report DOE/SR-WM-79-3, U. S. Department of Energy, Savannah River Operations office, Aiken, SC, April 1980.

4. Alternatives for Long-Term Management of Defense High-Level Radioactive Waste, Hanford Reservations, Richland, WA., U. S. ERDA Report, ERDA-77-44, U. S. Energy Research and Administration, Washington, DC, September 1977.

5. Alternatives for Long-Term Management of Defense High-Level Radioactive Waste, Savannah River Plant, Aiken, SC, U. S. ERDA Report, ERDA-77-42/1, U. S. Energy Research and Development Administration, Wash. DC, May 1977.

6. Alternatives for Long-Term Management of Defense High-Level Radioactive Waste, Idaho Chemical Processing Plant, Idaho Falls, ID, U. S. ERDA Report, ERDA-77-43, U. S. Energy Research and Development Administration, Wash. DC, September 1977. 
7. High-Level Radioactive Waste Management Alternatives, USAEC Report WASH-1297, U. S. Atomic Energy Commission, Washington, DC, May 1974.

8. Stone, J. A., Goforth, S. T., and Smith, P. K., Preliminary Evaluation of Alternative Forms for Immobilization of Savannah River Plant High-Level Waste, USDOE Report DP-1545, U. S. Department of Energy, Savannah River Laboratory, Aiken, SC, December 1979.

9. Kemp, J. B., Crandall, D. B., and Brothers, G. W., Proceedings of the National Waste Terminal Storage Program Information Meeting, ONWI-62, Office of Nuclear Waste Isolation, Columbus, $\mathrm{OH}$, October 1979.

10. Mendel, J. E., The Storage and Disposal of Radioactive Waste as Glass in Canisters, USDOE Report PNL-2764, U. S. Department of Energy, Battelle-Pacific Northwest Laboratory, December 1978.

11. Plodinec, M. J., Development of Glass Compositions for Immobilization of SRP Waste. USDOE Report DP-1517, U. S. Department of Energy, Savannah River Laboratory, Aiken, SC, 1979.

12. Wiley, J. R., Effluent and Environmental Radiation Surveillance, ASTM STP 698, J. J. Kelley, Ed. American Society for Testing and Materials, Philadelphia, PA, 1980, P. 233.

13. Wiley, J. R., Bibler, N. E., Dukes, M. D., and Plodinec, M. J., Glass as a Matrix for SRP High Level Waste. USDOE Report DPST-79-294, Savannah River Laboratory, Aiken, SC, January 1980.

14. Simmons, J. H., Macedo, P. B., Barkatt, A., and Litovitz, T. A., Nature, Vol. 278, 1979, p. 729. 
15. Moore, J. G., Newman, E., and Rogers, G. C., Radioactive Waste Fixation in FUETAP (Formed Under Elevated Temperature and Pressure) Concretes - Experimental Program and Initial Results. USDOE Report ORNL/TM-6573, U. S. Department of Energy, Oak Ridge National Laboratory, Oak Ridge, TN, 1979.

16. Weeren, H. O., and Perona, J. J., "A Preliminary Engineering and Economic Analysis of the Fixation of High-Level Wastes in Concrete." USDOE Report ORNL/TM-6863, U. S. Department of Energy, Oak Ridge National Laboratory, Oak Ridge, TN, 1979.

17. Roy, D. M., and Gouda, G. R., Nucl. Tech., Vol. 40, 1978, p. 214 .

18. Roy, D. M., and Gouda, G. R., Hot Pressed Cement in Radioactive Waste Management. Final Report to Nuclear Waste Technology Program, Subcontract BSA-841, Battelle Pacific Northwest Laboratories. Materials Research Laboratory, Pennsylvania State University, University Park, PA, 1974.

19. McCarthy, G. J., Nuc1. Tech., Vo1 44, 1979, p. 451.

20. McCarthy, G. J., Nucl. Tech., Vol. 32, 1977, p. 92.

21. McCarthy, G. J., White, W. B., Komarneni, S., Scheetz, B. E., Freaborn, W. P., and Smith, D. K., Ceramics in Nuclear Waste Management. USDOE Report CONF-790420, U. S. Department of Energy, Washington, DC, 1979, p. 274.

22. AhIstrom, P. E., USNRC Report NUREG/CP-0005, Nuclear Regulatory Commission, Washington, DC, 1979, pp. 283-316.

23. Ringwood, A. E., Kesson; S. E., Ware, N. G., Hibberson, W., and Major, A., Nature, Vol. 278, 1979, p. 219. 
24. Ringwood, A. E., Safe Disposal of High-Level Nuclear Reactor

Wastes: A New Strategy. Australian National University Press, Canberra, 1978 .

25. Ringwood, A. E., Kesson, S. E., hare, G. N., Hibberson, W. O., and Major, A., "The SYNROC Process: A Geochemical Approach to Nuclear Waste Immobilization." Geochemistry (in press).

26. Larker, H. T., Ceramics in Nuclear Waste Management. USDOE Report CONF-790420, U. S. Department of Energy, Washington, DC, 1979 , p. 169 .

27. Quinby, T. C., U. S. Patent 4,072,501, 7, Feb. 1978.

28. Aaron, W. S., Quinby, T. C., and Kobist, E. H., Cermet HighLevel Waste Forms, USDOE Report ORNL/TM-6404, U. S. Department of Energy, Oak Ridge National Laboratory, Oak Ridge, TN, 1978.

29. Aaron, W. S., Quinby, T. C., and Kobist, E. H., Ceramics in Nuclear Waste Management. USDOE Report CONF-790420, U. S. Department of Energy, Washington, DC, 1979, p. 164.

30. High-Level Waste Program Progress Report for April 1, 1979, through June 30, 1979. USDOE Report ORNL/TM-7013, U. S. Department of Energy, Oak Ridge National Laboratury, Oak Ridge, TN, 1979 , pp. 21-30.

31. Rusin, J. M., Lokken, R. 0., Lukacs, J. M., Sump, K. R., Browning, M. F., and McCarthy, G. J., "Multibarrier Waste Forms, Part I: Development." USDOE Report PNI-2668-1, U. S. Department of Energy, Pacific Northwest Laboratory, Richland, WA, 1978. 
32. Rusin, J. M., Gray, W. J., and Wald, J. W., Multibarrier Waste Form, Part II: Characterization and Evaluation. USDOE Report PNL-2668-2, U. S. Department of Energy, Pacific Northwest Laboratory, Richland, WA, 1979.

33. Jardine, I. J., and Steindler, M. J., A Review of MetalMatrix Encapsulation of Solidified Radioactive High-Level Waste. USDOE Report ANL-78-19, U. S. Department of Energy, Argonne National Laboratory, Argonne, II, 1978.

34. Knapp, W. R., and Smith, E. R., U. S. Patent 3, 254, 979, Aug. 1962 .

35. van Geel, J., Eschrich, H., Dobbels, F., Favre, P., and Sterner, H., USNRC Report NUREG/CP-0005, Nuclear Regulatory Commission, Washington, DC, 1979, pp. 341-389.

36. Heimerl, W., Ceramics in Nuclear Waste Management. USDOE Report CONF-790420, U. S. Department of Energy, Washington, DC, 1979, p. 97.

37. Lamb, K. M., Final Report: Development of a Metal Matrix for Incorporating High-Level Commercial Waste. USDOE Report ICP-1144, Allied Chemical Corporation, Idaho National Engineering Laboratory, Idaho Falls, ID, 1978.

38. Lamb, K. M., and Cole, H. S., Development of a Pelletized Waste Form for High-Level ICPP Zirconia Wastes. USDOE Report ICP-1185, Allied Chemical Corporation, Idaho National Engineering Laboratory, Idaho Falls, ID, 1979. 
39. Lackey, W. J., Blanco, R. E., and Lotts, A. L., Application of Sol-Gel Technology to Fixation of Nuclear Reactor Waste. Oak Ridge National Laboratory, Oak Ridge, TN, (to be published).

40. Lackey, W. J., and Selle, J. E., Assessment of Gel-Sphere-Pac Fuel for Fast Breeder Reactors. USDOE Report ORNI-5468, U. S. Department of Energy, Oak Ridge National Laboratory, Oak Ridge, $\mathrm{TN}, 1978$.

41. Billington, D. S., and Crawford, J. H., Radiation Damage in Solids, Princeton University Press, Princeton, NJ, 1961.

42. Jenks, G. H., and Bopp, C. D., Energy Storage in High-Leve1 Radioactive Waste and Simulation and Measurement of Stored Energy with Synthetic Wastes, USAEC Report ORNL-TM-3781, U. S. Atomic Energy Commission, Oak Ridge National Laboratory, Oak Ridge, TN, January, 1973.

43. Roberts, F. P., Jenks, G. H., and Bopp, C. D., Radiation Effects on Solidified High-Level Waste, Pt. I - Stored Energy, ERDA Report BNL-1944, U. S. Energy Research and Development Administration, Battelle-Pacific Northwest Laboratory, Richland, WA, January, 1976.

44. Turcotte, R. P., Radiation Effects on Solidified High-Level Wastes, Pt. 2 - Helium Behavior, ERDA Report BNWL-2051, U. S. Energy Research and Developemnt Administration, BattellePacific Northwest Laboratories, Richland, WA, May 1976.

45. Malow, G., and Andreson, H., Scientific Basis for Nuclear Waste Management, Vol. I, Ed. G. J. McCarthy, Plenum Press, N. Y. 1979, p. 109. 
46. Mendel, J. E., Ross, W. A., Roberts, F. P., Turcotte, R. P., Tatayama, Y. B., and Westik, Jr, J. H., Management of Radioactive Wastes from the Nuclear Fuel Cvcle, IAEA-SM-207/100, Vol. II, International Atomic Energy Agency, Vienna, 1976.

47. Hall, A. R., Dalton, J. T., Hudson, B., and Marples, J. A. C., Management of Radioactive Wastes from the Nuclear Fuel Cycle, IAEA-SM-207/24, Vol. II, International Atomic Energy Agency, 1976.

48. Scheffler, $\mathrm{K}$, and Riege, U., Investigations on the Long-Term Radiation Stability of Borosilicate Glasses Against Alpha Emitters, KFK 2422, Kernforschungszentrum Karlsruhe, April, 1977.

49. Mendel, J. E., Nuclear Tech., Vol. 32, 1977, p. 72.

50. Chikalla, T. D., Ceramic and Glass Radioactive Waste Forms, CONF-770102, U. S. Energy Research and Development Administration, Washington, DC, January, 1977.

51. Turcotte, R. P., and Roberts, F. P., Ceramic and Glass Radioactive Waste Forms, CONF-770102, U. S. Energy Research and Development Administration, Washington, DC, January, 1977.

52. Primak, William, Ceramic and Glass Radioactive Waste Forms, CONF-770102, U. S. Energy Research and Development Administration, Washington, DC, January, 1977.

53. Bibler, N. E. and Kelley, J. A., Effect of Internal Alpha Radiation on Borosilicate Glass Containing Savannah River Plant Waste, USDOE Report DP-1482, U. S. Department of Energy, Savannah River Laboratory, Aiken, SC, 1978. 
54. Mendel, J. E., et al. Annual Report on the Characteristics of HighLevel haste Glasses, USDOE Report BNWL-2252, U. S. Department of Energy, Battelle-Pacific Northwest Laboratories, Richland, WA, June 1977.

55. Dienes, G. J., J. Phys. Chem. Solids, Vol. 13, 1960, p. 272.

56. Primak, W., Fuchs, L. W. and Day, P. Phys. Rev. Vol. 92, 1953, p. 1064 .

57. Primak, W., J. Phys. Chem. Solids, Vol 13, 1960, p. 279.

58. Primak, W. and Edwards, E., Phys. Rev. Vol. 128, 1962, p. 2580.

59. Primak, W. and Kampwirth, R., J. Appl. Phys. Vol. 39, No. 12, 1968 , p. 5651 .

60. Primak, W. and Kampwirth, R., J. Appl. Phys. Vol 39, No. 13, 1968, P. 6010.

61. Primak, W. and Kampwirth, R., J. Appl. Phys. Vol. 40, No. 2, 1969 , p. 685 .

62. EerNisse, E. P., J. App1. Phys., Vol. 45, No. 1, 1974, p. 167.

63. EerNisse, E. P. and Norris, C. B., J. Appl. Phys., Vol. 45, No. 12,1974, p. 5196 .

64. Primak, W., The Compacted States of Vitreous Silica, Gordon and Breech, NY, 1975.

65. Dellin, T. A., Tichenor, D. A. and Barsis, E. H., J. Appl. Phys., Vol. 48, No. 3, 1977, p. 1132.

66. Primak, W., Nucl. Sci. ㅌ Eng., Vol. 65, 1978, p. 141.

67. Shelby, J. E., J. Appl. Phys., Vol. 50, No.' 5, 1979, p. 3702. 
68. Klaffky, R. W., Swyler, K. J. and Levy, P. K., Ceramics in Nuclear Waste Management, USDOE Report CONF-790420, U. S. Department of Energy, Washington, DC, 1979, p. 310.

69. Swyler, K. W., Klaffky, R. W. and Levy, P. W., Scientific Basis for Nuclear Waste Management, Vol. I, G. J. McCarthy, Ed, Plenum Press, NY, 1979, p. 349.

70. Swyler, K. W., Klaffky, R. W. and Levy, P. K., Proceedings of the National Waste Terminal Storage Program Information Meeting, ONWI-62, Office of Nuclear Waste Isolation, Columbus, OH, October, 1979.

71. Spitsyn, V. I. and Balukova, V. D., Scientific Basis for Nuclear Waste Management, Vo1. 2, Symposium G-Materials Research Society Annual Meeting, Cambridge, MA., November, 1979, (to be published).

72. Wiffen, F. W. and Bloom, E. E., Nucl. Tech., Vol. 25, 1975, p. 113 .

73. Mylonas, C. and Truel1, R., J. Appl. Phys., Vol. 29, 1958, p. 1252 .

74. Ross, W. A., et al, Annual Report on the Characterization of High-Level Waste Glass, USDOE Report PNL-2625, U. S. Department of Energy, Battelle-Memorial Institute, Pacific Northwest Laboratory, June 1978.

75. Weber, W. J., et al, Ceramics in Nuclear Waste Management. USDOE Report CONF-790420, U. S. Department of Energy, Washington, DC, 1979, p. 294. 
76. Kelley, J. A., Evaluation of Glass as Matrix for Solidification of SRP Waste, ERDA Reports DP-1382 and DP-1397, U. S. Department of Energy, Savannah River Laboratory,"Aiken, SC, 1975.

77. Plodinec, M. J. and Wiley, J. R., Evaluation of Glass as a Matrix for Solidifying SRP Waste: Properties of Glasses Containing Li 2 O, USDOE Report DP-1498, U. S. Department of Energy, Savannah Laboratory, Aiken, SC, 1979.

78. Bradley, D. J., Leaching of Fully Radioactive High Level Waste Glass, USDOE Report PNL-2664, U. S. Department of Energy, Battelle Memorial Institute, Pacific Northwest Laboratory, Richland, WA, 1978.

79. Tuck, D. G., Int. J. App1. Rad. and Isotopes, Vol. 15, 1964, p. 49.

80. Dran, J. C., Langevin, Y., Maurette, M. and Pettit, J. C., Scientific Basis for Nuclear Waste Management, Vol. 2, Symposium G - Materials Research Society Annual Meeting, Cambridge, MA, November 1979, (to be published).

81. Pabst, H., Am. Mineral, Vol. 37, 1952, p. 137.

82. Ewing, R. C., Science, Vo1. 192, 1976, p. 1336.

83. Haaker, R. F. and Ewing, R. C., Ceramics in Nuclear Waste Management, USDOE Report CONF-790420, U. S. Department of Energy, Washington, DC, 1979 , p. 305 .

84. Wasilewski, P. J., Senftle, F. W., Vas, J. E., Thorpe, A. N. and Alexander, C. C., Radiation Effects, Vol. 17, 1973, p. 191.

85. Haaker, R. F and Ewing, R. C., Scientific Basis for Nuclear Waste Management, Vol. 2, Symposium G-Materials Research Society Annual Meeting, Cambridge, MA, November 1979, (to be published). 
86. Ewing, R. C. and Haaker, R. F., Quarterly Progress Report, Research and Development Activities, High Level Waste Immobilization Program, Oct-Dec. 1978, USDOE Report PN-2999-4, U. S. Department of Energy, Pacific Northwest Laboratory, Richland, WA, May 1979, p. 17.

87. Norris, A. E., Proceedings of the National Waste Terminal Storage Program Information Meeting, ONWI-62, Office of Nuclear Waste Isolation, Columbus, OH, Oct. 30 - Nov. 1, 1979.

88. Bryant, E. A., Cowan, G. A., Daniels, W. R. and Maeck, W. J., Am. Chem. Soc. Symp. Series, No. 35,1976, p. 89.

89. Ringwood, A. E., Scientific Basis for Nuclear Waste Management, Vol. 2, Symposium G-Materials Research Society Annual Meeting, Cambridge, MA, November 1979, (to be published).

90. Clinard, F. W. and Hurley, G. F., Ceramics in Nuclear Waste Management, USDOE Report CONF-790420, U. S. Department of Energy, Washington, DC, 1979.

91. Mulford, R. N. R. and Mueller, B. A., Measurements of Helium Release from Materials Containing ${ }^{238}{ }_{\text {PuO }}$, USAEC Report LA-5215, U. S. Atomic Energy Commission, Los Alamos Scientific Laboratory, Los Alamos, NM, July, 1973.

92. Bauer, W., J. Nucl. Mater., Vol. 76 and 77,1978, p. 3.

93. Norton, F. J., J. Am. Ceram. Soc., Vol 36, 1953, P. 90.

94. Shelby, J. E., J. Appl. Phys., Vol. 44, 1973, p. 3880.

95.. Shelby, J. E., J. Appl. Phys., Vol. 44, 1973, p. 4588.

96. Shelby, J. E. and Keeton, S. C., J. Appl. Phys., Vol. 45, 1974 p. 1458 . 
97. Shelby, J. E., J. Non-Cryst. Solids, Vol. 14, 1974, p. 288.

96. Shelby, J. E., J. Appl. Phys., Vol. 45, 1974, p. 2146.

99. Sinelby, J. E., J. Appl. Phys., Vol. 45, 1974, p. 2536.

100. Shelby, J. E., J. Appl. Phys., Vo1. 46, 1975, p. 4510.

101. Shelby, J. E., J. Appl. Phys., Vol. 49, 1978, p. 2748.

102. Thomas, G. J., Bauer, W., Mattern, P. L. and Granoff, B., Proceedings of the American Chemical Society Meeting, SAND 75-8718, Chicago, IL, August, 1975.

103. Mattern, P. L., Shelby, J. E., Thomas, G. J., Bauer, W., J. Nucl. Mater., Vol. 63, 1976, p. 317.

104. Mueller, B. A., Rohr, D. D., Mulford, R. N. R., Helium Release and Microstructural Changes in $238_{\mathrm{PuO}_{2}}$. USAEC Report LA-5524, U. S. Atomic Energy Commission, Los Alamos Scientific Laboratory, Los Alamos, NM, April 1974.

105. McDonell, W. R., Sheehan, J. E. and Sisson, R. D., Trans. Am. Nucl. Soc., Vol. 22, 1975, p. 214. 
TABLE 1

SUMMARY OF RADIOACTIVE WASTES IN THE U.S. [2]

\begin{tabular}{|c|c|c|}
\hline Class & Quantity & $\begin{array}{c}\text { Percent } \\
\text { Commercial }\end{array}$ \\
\hline Liquid High-Level Waste & 75 million gallons & 1 \\
\hline Transuranic Solid Waste & $1200 \mathrm{~kg}$ of TRU nuclides & 10 \\
\hline $\begin{array}{l}\text { Spent Fuel Discharged } \\
\text { from Commercial Reactors }\end{array}$ & 2500 tons (heavy metal) & 100 \\
\hline Low-Level Solid Waste & 66 million $\mathrm{ft}^{3}$ (buried) & 25 \\
\hline Uranium Mill Tailings & 140 million tons & 100 \\
\hline
\end{tabular}


TABLE 2

U. S. HIGH-LEVEL NUCLEAR WASTES [3]

\begin{tabular}{|c|c|c|c|c|c|c|}
\hline \multirow{2}{*}{$\begin{array}{c}\prime \\
\text { Source } \\
\end{array}$} & \multirow[b]{2}{*}{ Form } & \multicolumn{2}{|c|}{1978 Quantities } & \multicolumn{2}{|c|}{$1990 \mathrm{H} / \mathrm{gh}$ EST. } & \multirow{2}{*}{$\begin{array}{l}\text { Solidification Vol } \\
\text { of } 1990 \text { Wastes, }{ }^{3} 10^{3} \mathrm{ft}^{3}\end{array}$} \\
\hline & & $10^{6} \mathrm{Bal}$ & $10^{6} \mathrm{CI}$ & $10^{5} 8 \mathrm{a} 1$ & $10^{6 \mathrm{CI}}$ & \\
\hline \multirow[t]{2}{*}{ Hanford Plant } & $\begin{array}{l}\text { Alk. Salt/Sludge/ } \\
\text { Liquor }\end{array}$ & 50 & 190 & 65 & 230 & 660 \\
\hline & $\begin{array}{l}\text { Separated }{ }^{90} \mathrm{Sr} / \mathrm{Y}, \\
{ }_{3}{ }^{\mathrm{C}} \mathrm{Cs} / \mathrm{Ba}\end{array}$ & - & 350 & - & 425 & \\
\hline $\begin{array}{l}\text { Idaho Chemical } \\
\text { Processing }\end{array}$ & AcId Calcine & 0.45 & 61 & 1.3 & 168 & 300 \\
\hline Plant & Actd Liquid & 2.5 & 13 & 1.2 & 8 & \\
\hline $\begin{array}{l}\text { Savannah } \\
\text { River Plant }\end{array}$ & $\begin{array}{l}\text { Alk. Salt/Sludge/ } \\
\text { liquor }\end{array}$ & 22 & 570 & 22 & 680 & 200 \\
\hline $\begin{array}{l}\text { Nuclear } \\
\text { Fuel }\end{array}$ & Alk. Sludge/Liquor & 0.6 & 64 & 0.6 & 48 & 7 \\
\hline Services & Acid Liquor & 0.01 & 2.1 & 0.01 & 1.6 & \\
\hline $\begin{array}{l}\text { Possible } \\
\text { Future } \\
\text { LWR Waste }\end{array}$ & Actd Liquor & 0.7 & 1900 & 5.2 & $14000^{c}$ & 460 \\
\hline
\end{tabular}

a. $25 \%$ loading of waste oxldes in waste form.

- No processing of spent fuels from comnercial nuclear power reactors is currently being performed in the

U. S., and offictal polfcy is presently to store rather than process spent fuel.

c. After at least 6 years' aging. 


\section{TABLE 3}

CHEMICAL COMPOSITION OF RECONSTITUTED SRP

HIGH-LEVEL WASTE (SALT AND SLUDGE) [5]

Constituent Concentration, molar

$\begin{array}{ll}\mathrm{NaNO}_{3} & 2.2 \\ \mathrm{NaNO}_{2} & 1.1 \\ \mathrm{NaAl}(\mathrm{OH})_{4} & 0.5 \\ \mathrm{NaOH} & 0.75 \\ \mathrm{Na}_{2} \mathrm{CO}_{3} & 0.3 \\ \mathrm{Na}_{2} \mathrm{SO}_{4} & 0.3 \\ \left.\mathrm{Fe}_{(\mathrm{OH}}\right)_{3} & 0.07 \\ \mathrm{MnO}_{2} & 0.02 \\ \mathrm{Hg}(\mathrm{OH})_{2} & 0.002 \\ \text { Other Solids } & 0.13^{\mathrm{a}}\end{array}$

a. Assuming an average molecular weight of 60 . 
TABLE 4

TYPICAL MATERIALS IN HIGH-LEVEL COMMERCIAL WASTE [7]

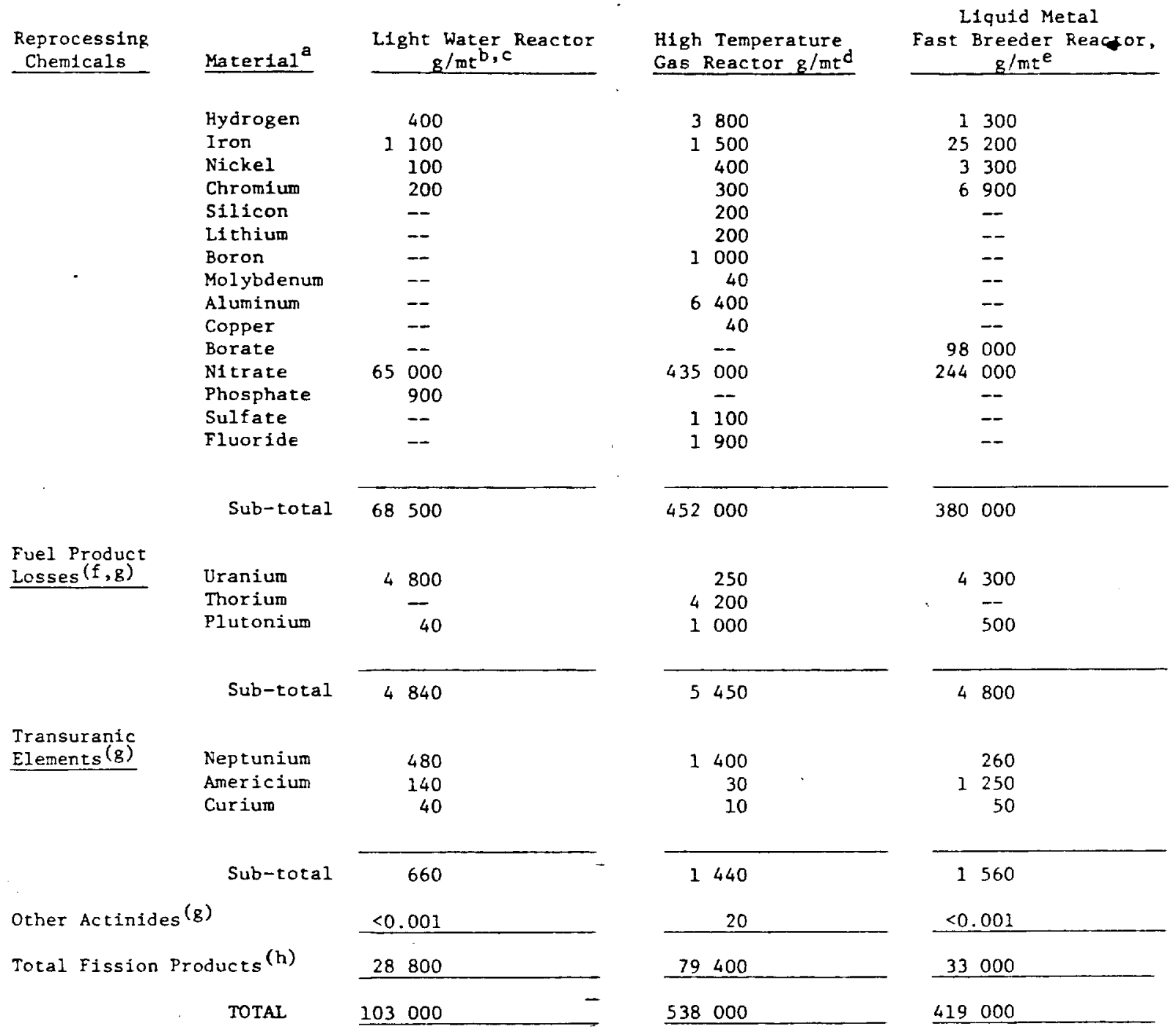

a. Most constituents are present in soluble, ionic form.

b. Water content is not shown; all quantities are rounded.

c. U-235 enriched PWR, using 378 liters of aoueous waste per metric ton, 33000 MWd/MT exposure.

(Integrated reactor power is expressed in megawatt-days [MWd] per unit of fuel in metric tons [MT].)

d. Combined waste from separate reprocessing of "fresh" fuel and fertile particles, using 3785 liters of agueous waste per metric ton, $94200 \mathrm{MWd} / \mathrm{MT}$ exposure.

e. Mixed core and blanket, with boron as soluble poison, $10 \%$ of cladding dissolved, 1249 liters per metric ton, $37100 \mathrm{MWd} / \mathrm{MT}$ average exposure.

f. $0.5 \%$ product loss to waste.

g. At time of reprocessing.

h. Volatile fission products (tritium, noble gases, iodine and bromine) excluded. 
TABLE 5

CANDIDATE FORMS FOR HIGH-LEVEL RADIOACTIVE WASTE [8]

\section{Waste Form}

Spent fuel elements

Borosilicate glass

High silica glass

FUETAP concrete

Hot pressed concrete

Taylored ceramic (Supercalcine)

Synroc ceramic

Cermet (Urea Process)

Glass marbles in metal matrix

Ceramic pellets in metal matrix

Coated ceramic

\section{Description}

$\mathrm{UO}_{2}$ pellets in Zircaloy or stainless steel sheaths packaged for disposal in metal canister [9]

Large cylinder $1-2$ ft diam. $x 10 \mathrm{ft}$ length formed by melting waste calclne and glass frit at $1150^{\circ} \mathrm{C}$ and casting into metal canister. Waste loading about 25 wt $\%$. [10-13]

Large cylinder formed by sintering waste calcine with porous glass frit at $1100-1200^{\circ} \mathrm{C}$. Waste loading about 18 wt \%. [14]

Large cylinder formed under elevated temperature and pressure $\left(150^{\circ} \mathrm{C}, 100 \mathrm{psi}\right)$. Waste loading about 12 wt $\%,[15,16]$

Dense monolith formed by hot pressing at $150-250^{\circ} \mathrm{C}$ and 25000 to $50000 \mathrm{psi}$. $[17,18]$

Crystalline body composed of stable and mutually compatable oxide phases,

including corundum, spirel, magnetoplumbite and uraninite. Formed by hot pressing or cold pressing and sintering to nearly full density. Waste loading 30-95 wt \% [19-22].

Crystalline body composed of titanate phases including perovskite, zirconolite, and hollandite, for commercial wastes, and nepheline for defense waste $[23-25]$. Formed by isostatic compaction $\left(1200^{\circ} \mathrm{C}\right.$, $30000 \mathrm{psi}$ ). Waste loading 30-70 wt \%.

Finely dispersed oxides in continuous metal phase formed from calcined waste pellets by $\mathrm{CO}$ reduction at $1200^{\circ} \mathrm{C}$. Waste loading $16 \%$. [26-29]

Waste glass marbles $1.3 \mathrm{~cm}$ diam. in cast $\mathrm{Pb}-\mathrm{Sn}$ alloy. Waste loading 4.4 wt $\%$. $[31-36]$

Sintered crystaline ceramic waste pellets $0.6 \mathrm{~cm}$ diam. in vacuum cast Al-Si alloy. Waste loading $56 \%$. $[31-33,35,37,38]$

Crystalline ceramic waste pellets coated with pyrolytic carbon and $\mathrm{Al}, \mathrm{O}$ and embedded in sintered copper or sand $[31,32,38]$. Spherical ceramic particles prepared by the Sol-gel process may also be used $(31,39,40)$. 
TABLE 6

PROJECTED RADIATION EXPOSURES OF WASTÉ FORMS (GLASS)

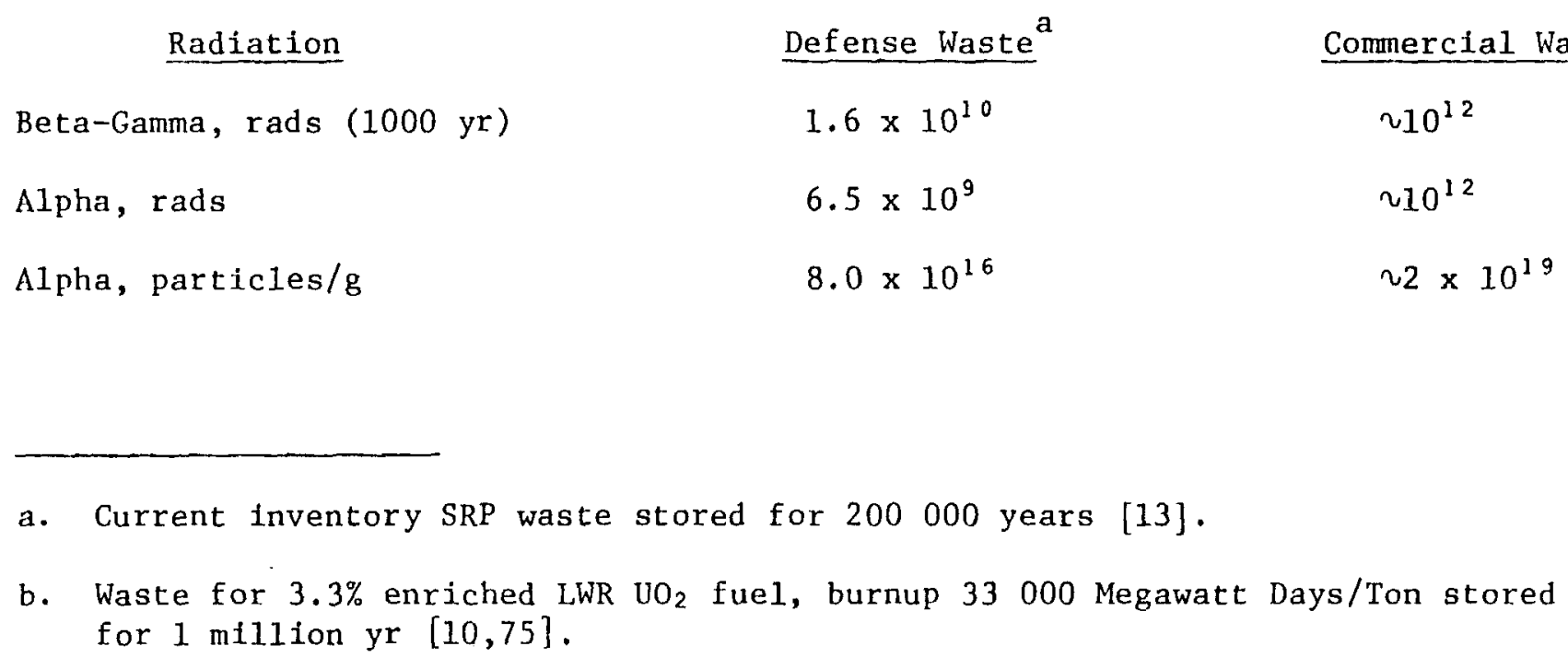


TABLE 7

ENERGY DISSIPATED IN ELASTIC COLLISIONS BY VARIOUS RADIATIONS IN RADIOACTIVE WASTES $[43]$

\begin{tabular}{|c|c|c|c|}
\hline Nuclear Particle & $\begin{array}{l}\text { Energy Dissipated } \\
\text { in Elastic } \\
\text { Collisions, kev } \\
\end{array}$ & $\begin{array}{c}\text { Cumulative Number of } \\
\text { Particles in Wastes } \\
\text { Aged } 12 \text { Years, } \\
10^{17} / \mathrm{cm}^{3} \\
\end{array}$ & $\begin{array}{c}\text { Cumulative Amount of } \\
\text { Collision Energy } \\
\text { Dissipation in wastes } \\
\text { Aged } 12 \text { Years, a } \\
10^{19} \mathrm{keV} / \mathrm{cm}^{3} \\
\end{array}$ \\
\hline $\begin{array}{l}\alpha-\text { recoil nuclei } \\
(100 \mathrm{keV})\end{array}$ & $100^{b}$ & 8.1 & 8.1 \\
\hline$\alpha(6 \mathrm{MeV})$ & 4 to $8^{b, c}$ & 8.1 & 0.3 to 0.6 \\
\hline $\begin{array}{l}B(>0.5 \mathrm{MeV}, \\
\text { average } 1.5 \mathrm{MeV})\end{array}$ & $<0.1^{\mathrm{d}}$ & 3 & $<0.3$ \\
\hline$y(2 \mathrm{MeV})$ & $<<0.1^{\mathrm{e}}$ & $<3$ & $<<0.3$ \\
\hline
\end{tabular}

a. For wastes from PWRs with UO $\mathrm{fuel}_{2} 2 \mathrm{ft}^{3}$ of waste per MTHM. (ORNL-TM-3965).

b. Assuming $T<E_{i}$, all of the kinetic energy of the particle is dissipated in elastic collisions with absorber-atoms and $T>E_{i}$, all of the kinetic energy of the particle is dissipated in electromagnetic interactions with absorber-electrons. $T=k i n e t i c$ energy of particles. $E_{i}=0.001 M_{2} \mathrm{MeV}$ where $M_{2}$ is the atomic weight of the projectile.

c. Also calculated for waste-type oxides using the method of Kinchin and Pease with $E_{i}$ as given above (Rept. Progr. Phys., 18, 1 (1955).

d. Based on conservatively high estimates for the number of displacements per beta particle together with a value of $50 \mathrm{eV}$ per permanent displacement.

e. J. H. Kinchin o R. S. Pease, Rept. Prog. Phys., 18, I (1955). 


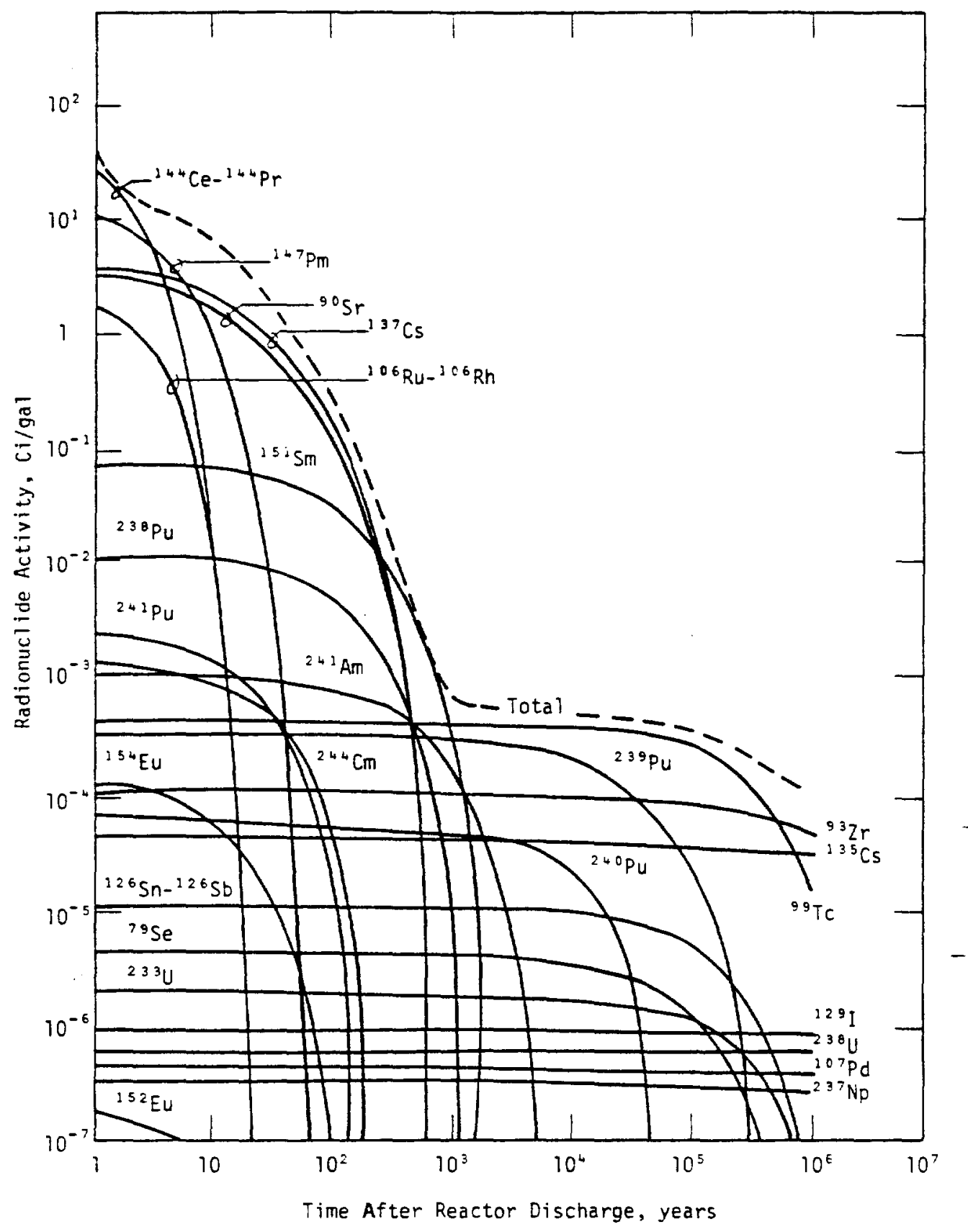

FIGURE 1. Radionuclide Composition of SRP High-Level Waste (1 to $10^{6} \mathrm{yr}$ after irradiation) [5] 


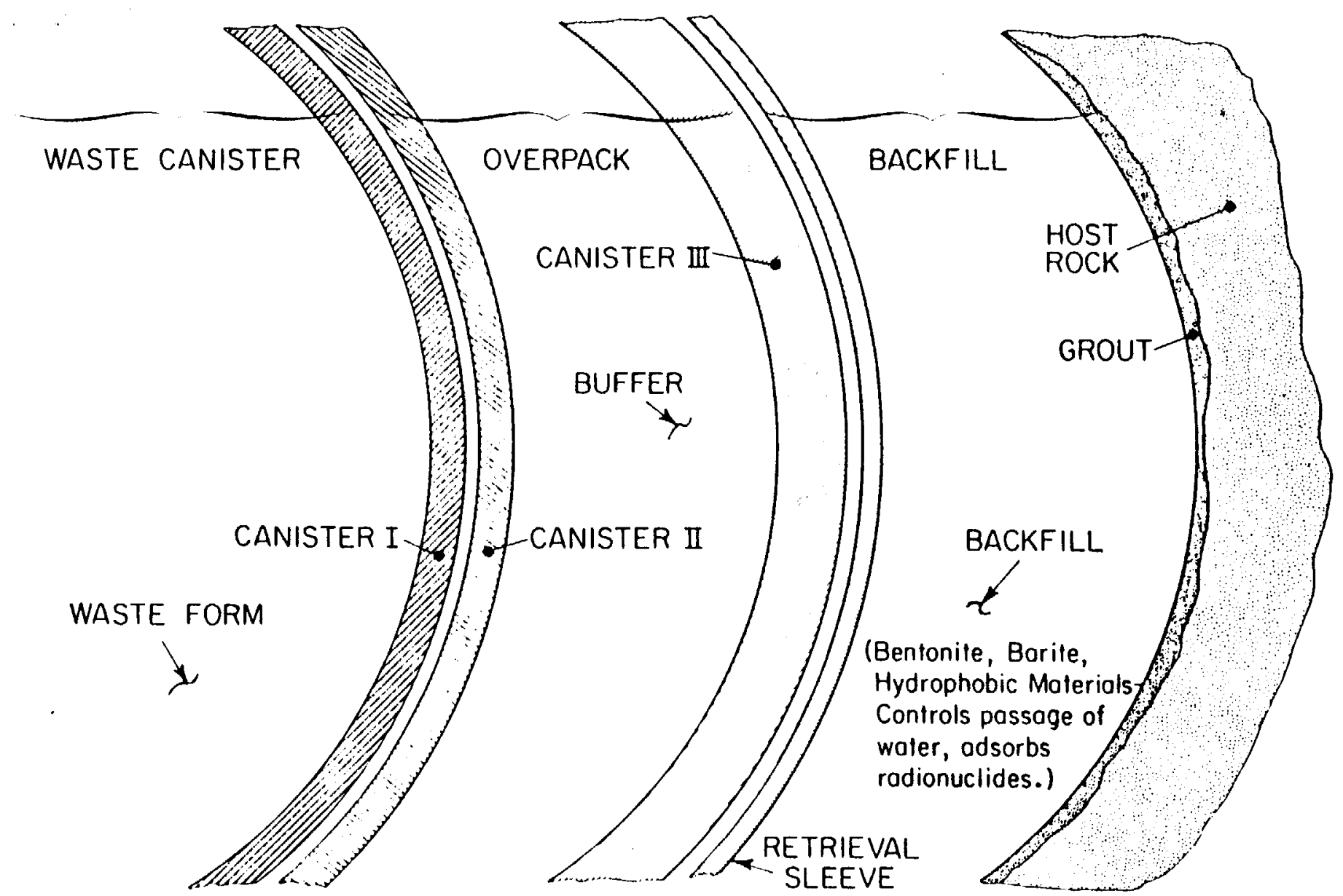

FIGURE 2. Engineered Barriers for Radioactive Waste Disposal 


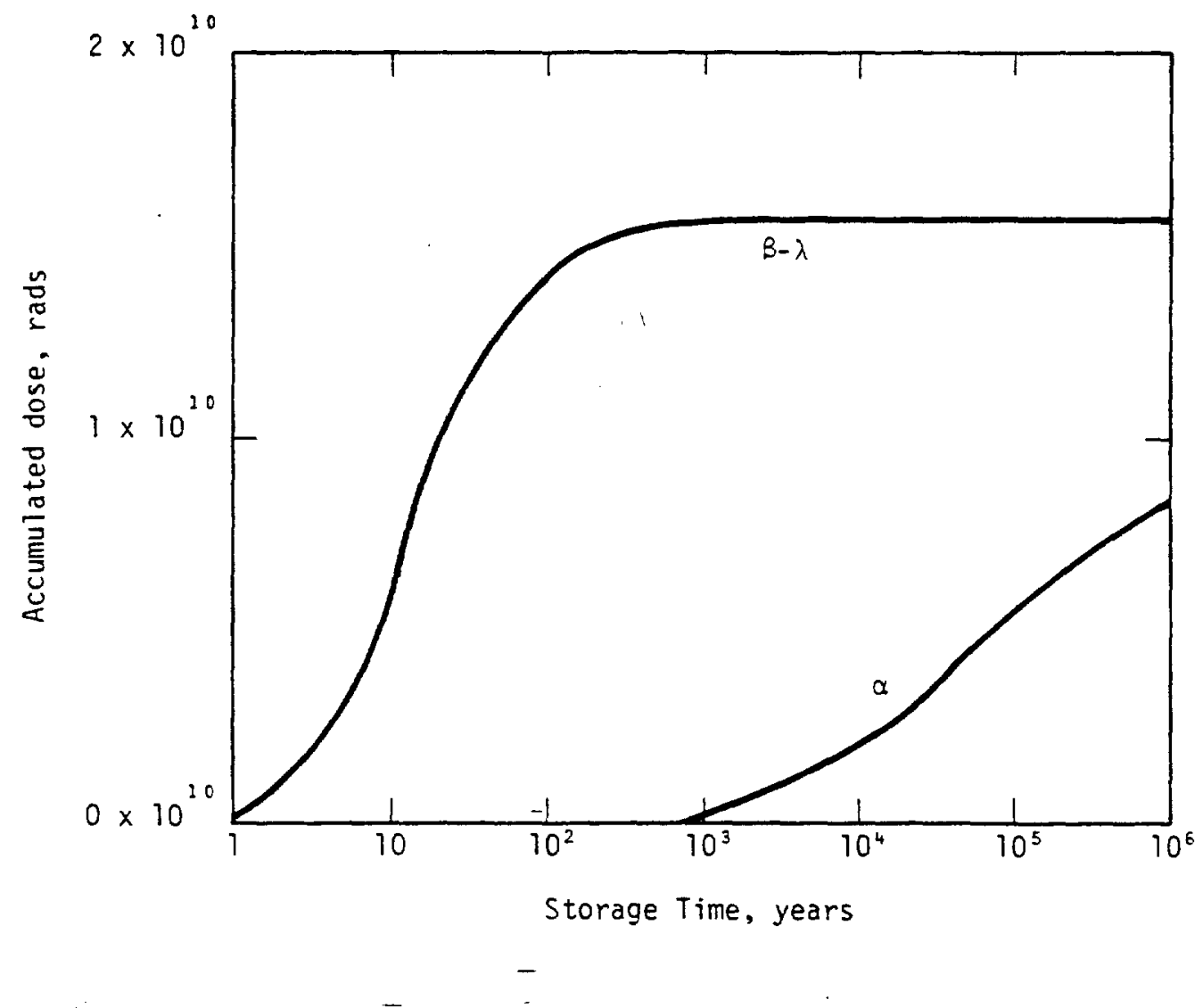

FIGURE 3. Accumulated Dose to SRP Waste Glass [13] 


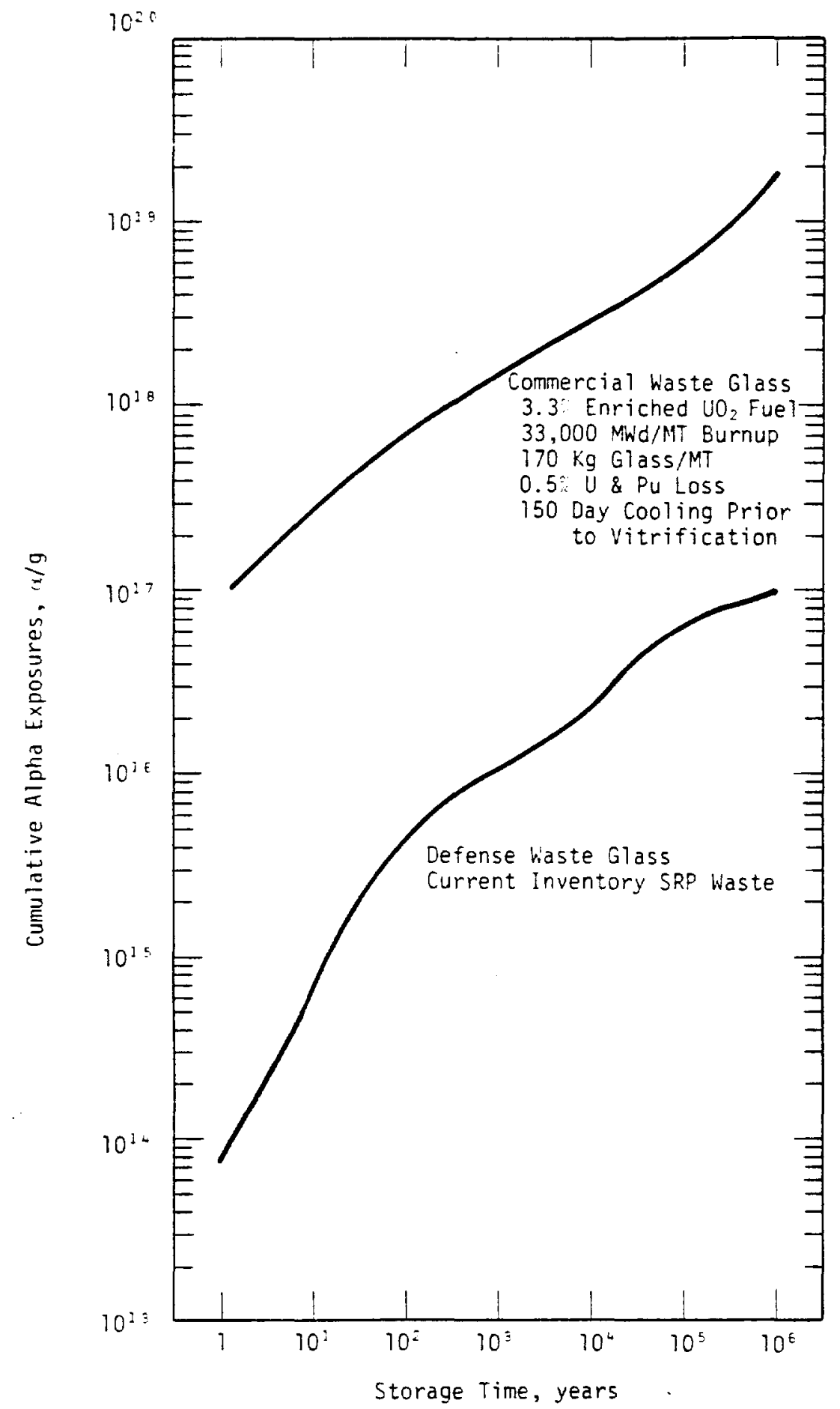

FIGURE 4. Accumulated Alpha Radiation Exposures for Commercial and Defense WasteForms [13,54] 


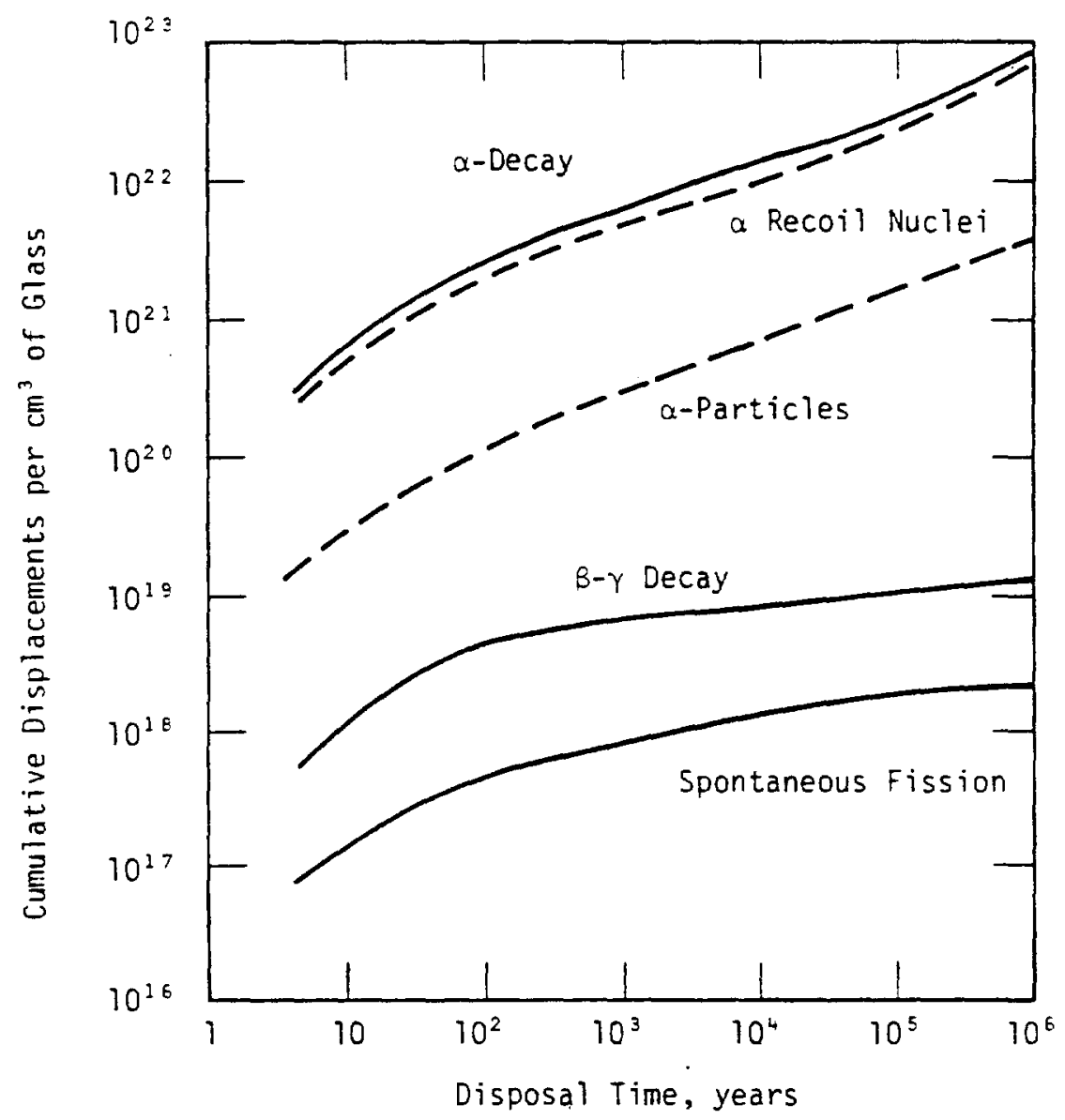

FIGURE 5. Cumulative Displacements Due to Different Decay Reactions in a Commercial Borosilicate Waste Glass [Adapted from ref. 45] 


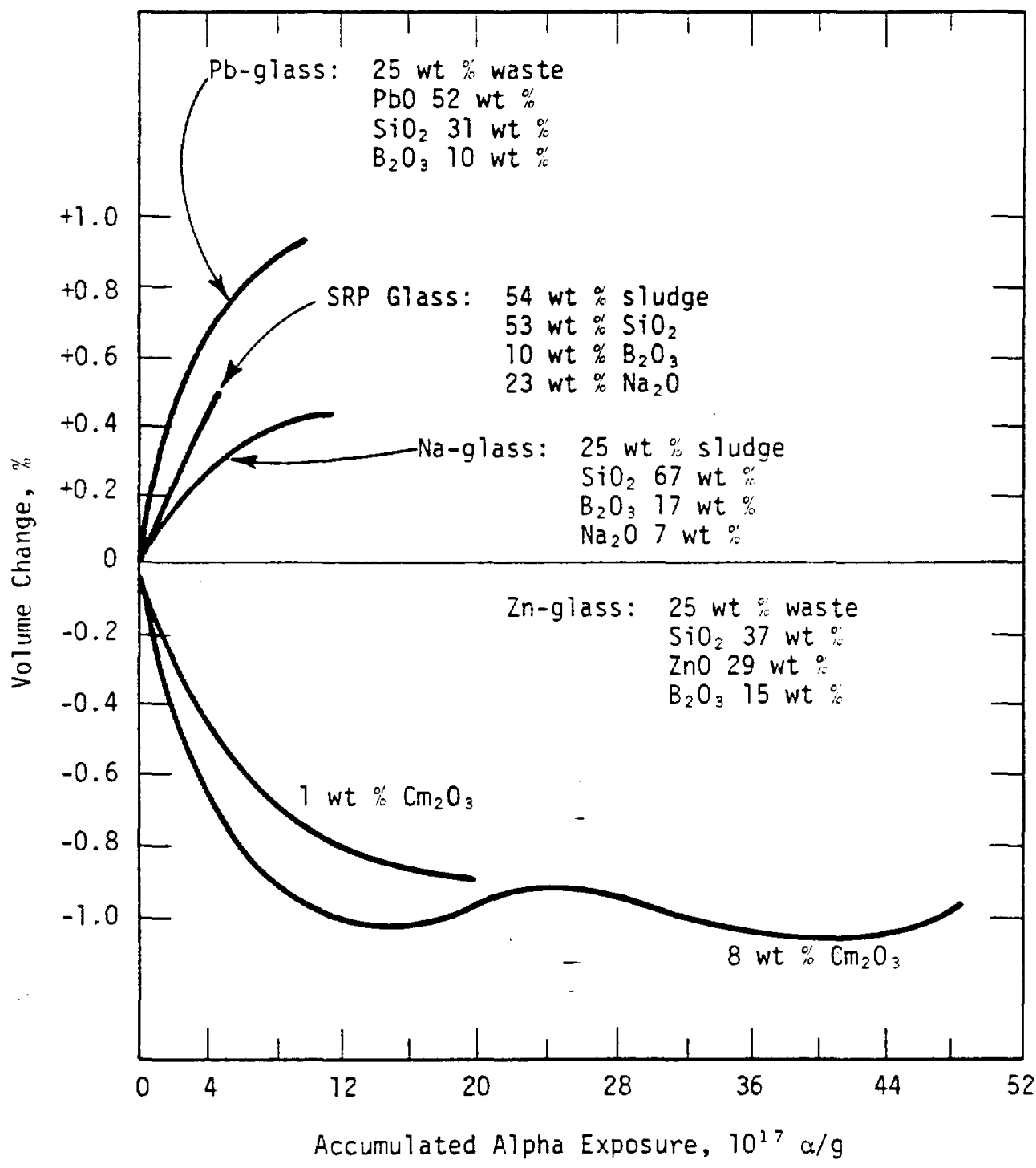

FIGURE 6. Alpha-Induced Volume Change for Several Glasses with Simulated Nuclear Waste [Adapted from ref. 10, 13] 


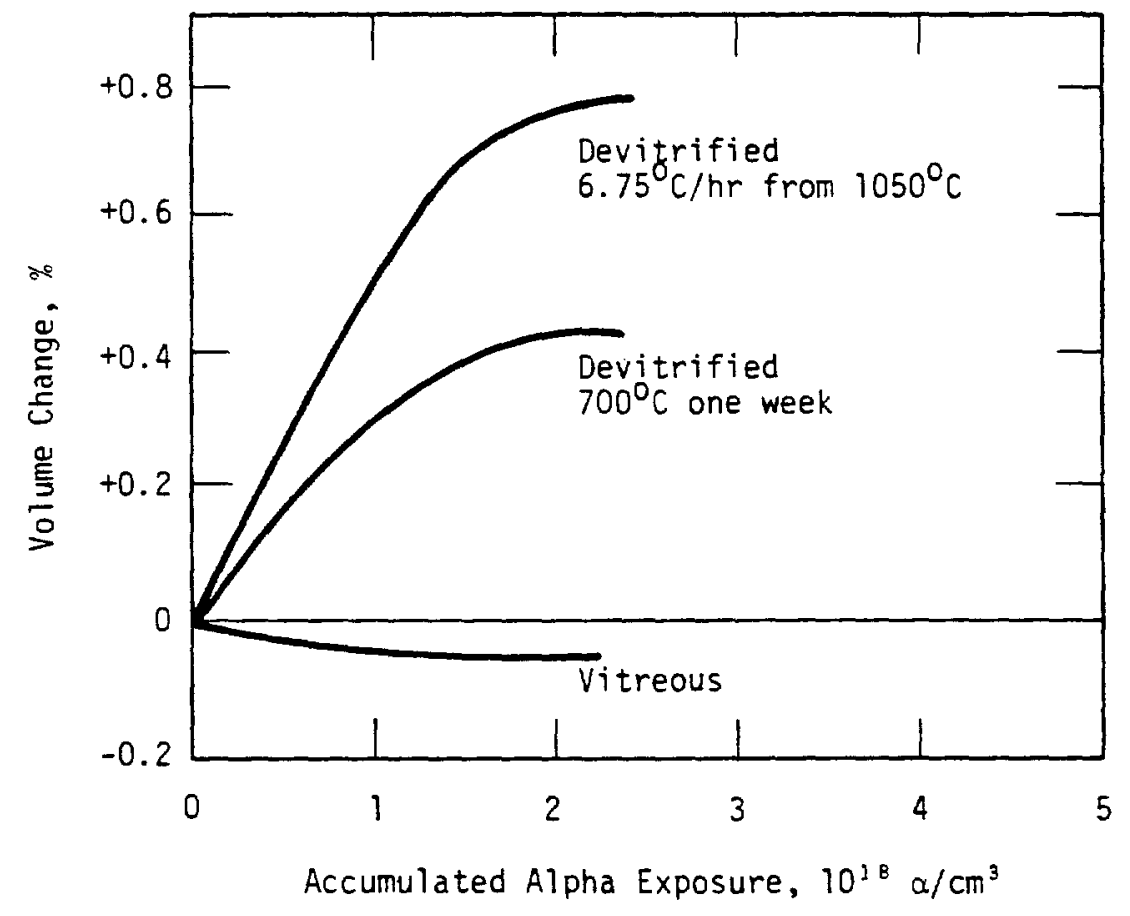

FIGURE 7. Effect of Devitrification on Volume Changes Produced by Alpha Radiation of a Simulated Waste Glass [Adapted from ref. 75] 


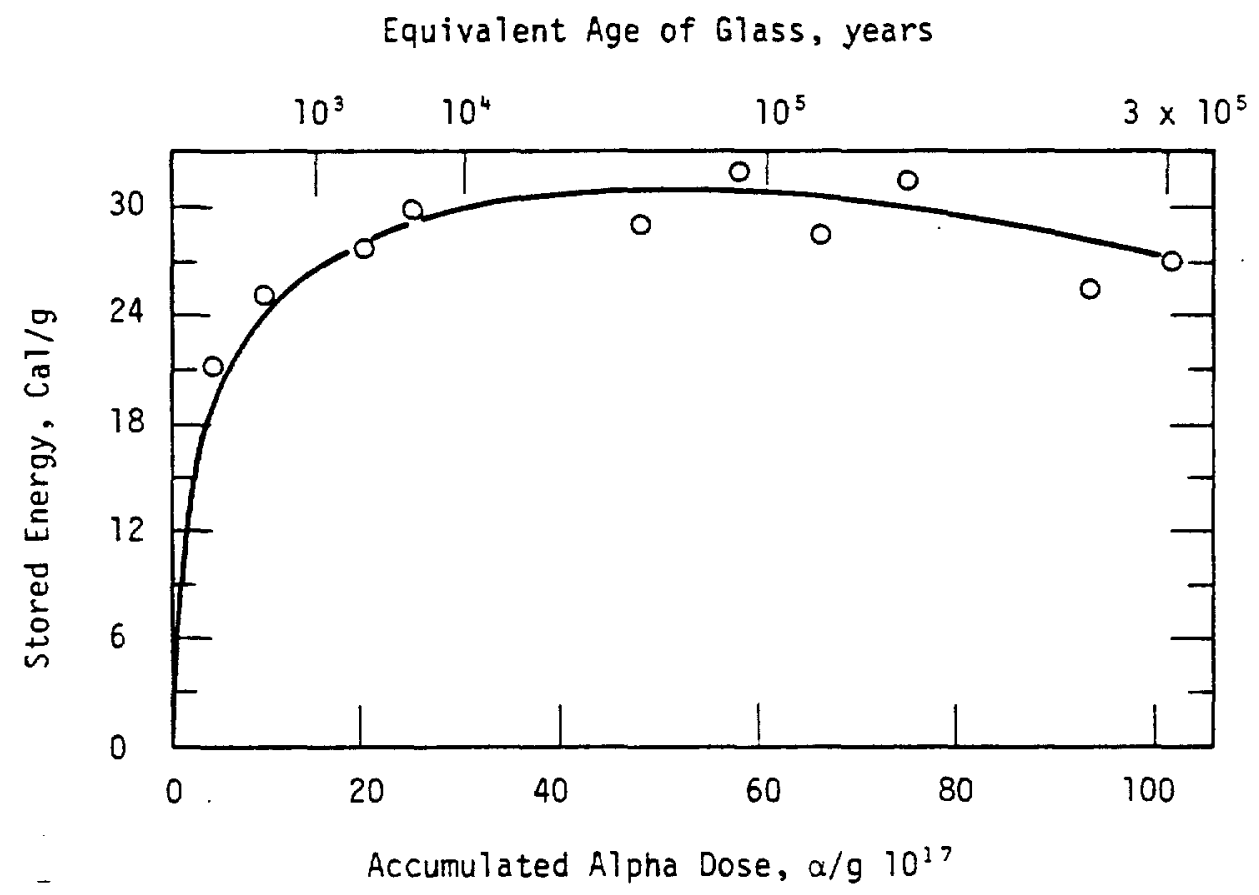

FIGURE 8. Stored Energy in Simulated Waste Glass [10] 


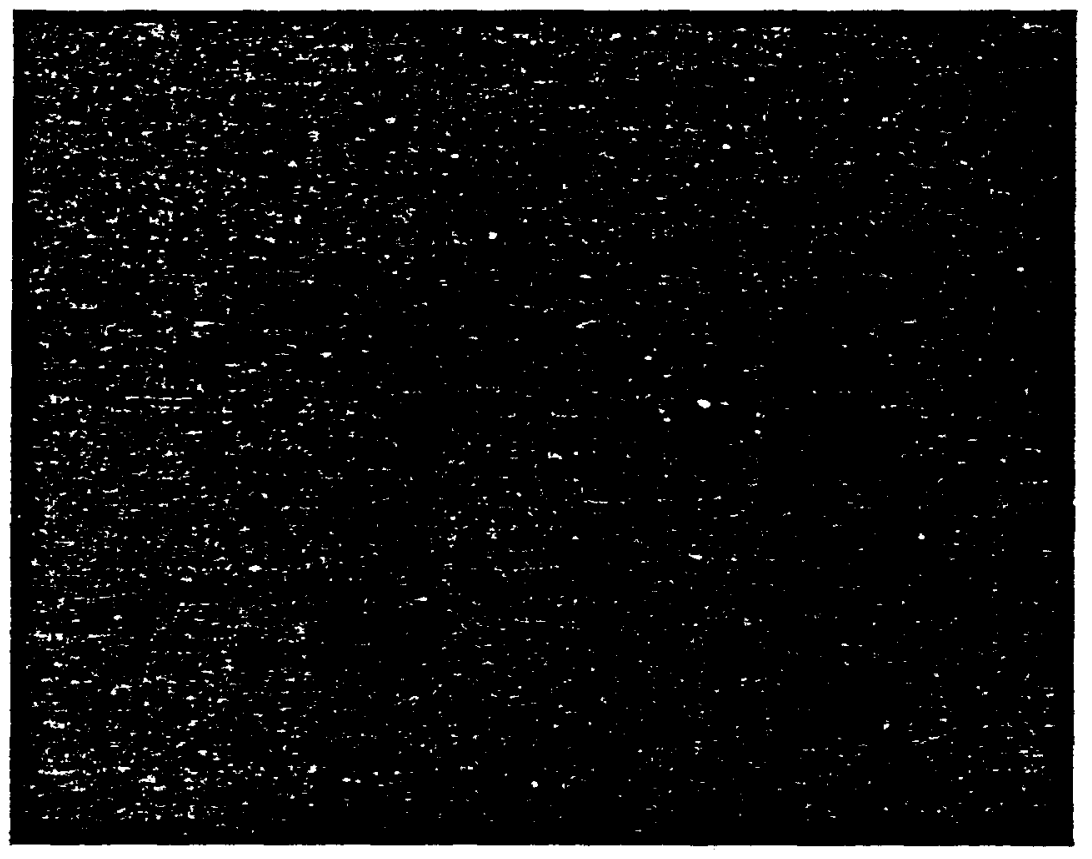

FIGURE 9. Surface Blistering of Alpha-Irradiated Simulated Waste Borosilicate Glass During Beam Heating in Scanning Electron Microscope. Note microcracking also observed [53]. 


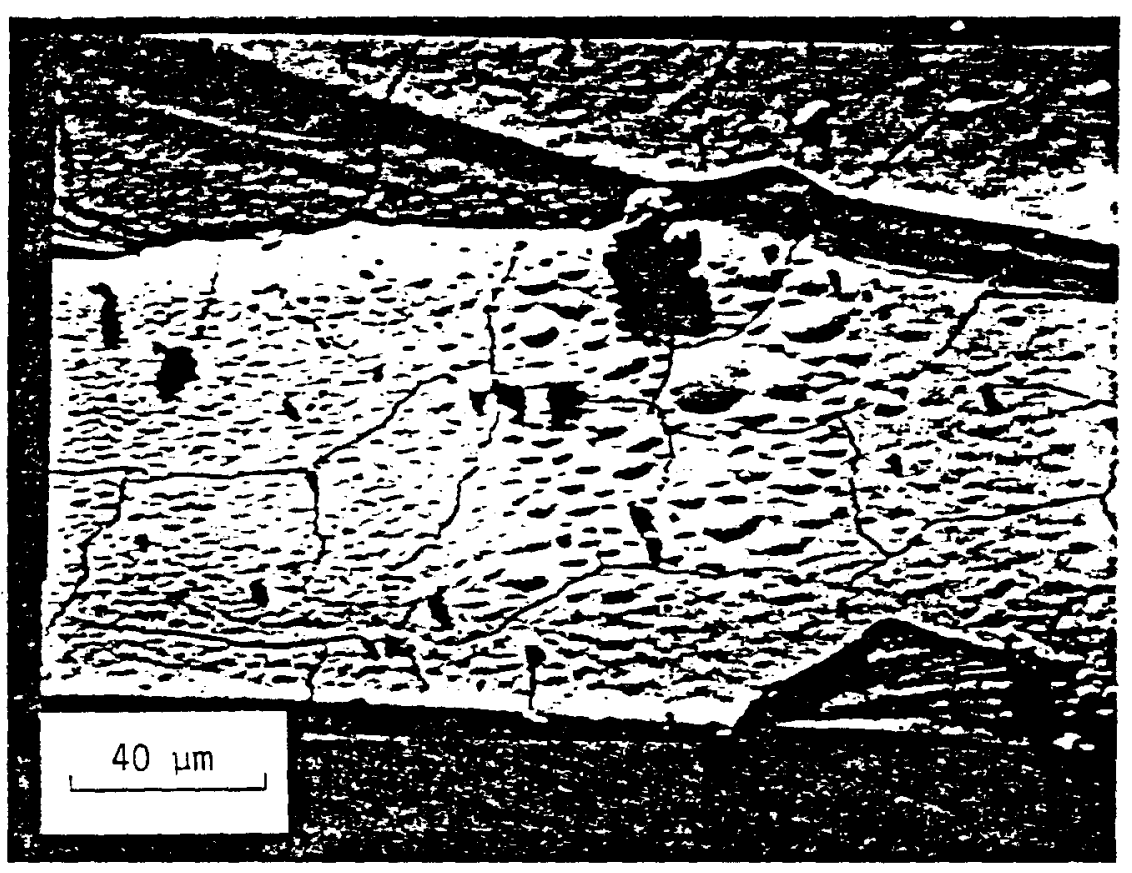

$p / 3$ 